\title{
Biomarkers and Utility of the Antioxidant Potential of Probiotic Lactobacilli and Bifidobacteria as Representatives of the Human Gut Microbiota
}

\author{
Olga V. Averina ${ }^{1, *}$, Elena U. Poluektova ${ }^{1}$, Mariya V. Marsova ${ }^{1}$ and Valery N. Danilenko ${ }^{1,2}$ \\ 1 Vavilov Institute of General Genetics, Russion Academy of Sciences, 119991 Moscow, Russia; \\ epolu@vigg.ru (E.U.P.); masha_marsova@mail.ru (M.V.M.); valerid@vigg.ru (V.N.D.) \\ 2 Institute of Ecology, Peoples' Friendship University of Russia (RUDN University), 117198 Moscow, Russia \\ * Correspondence: olgavr06@mail.ru
}

check for updates

Citation: Averina, O.V.;

Poluektova, E.U.; Marsova, M.V.; Danilenko, V.N. Biomarkers and Utility of the Antioxidant Potential of Probiotic Lactobacilli and Bifidobacteria as Representatives of the Human Gut Microbiota. Biomedicines 2021, 9, 1340. https:// doi.org/10.3390/biomedicines9101340

Academic Editor: Amedeo Amedei

Received: 28 July 2021

Accepted: 22 September 2021

Published: 28 September 2021

Publisher's Note: MDPI stays neutral with regard to jurisdictional claims in published maps and institutional affiliations.

Copyright: (c) 2021 by the authors. Licensee MDPI, Basel, Switzerland. This article is an open access article distributed under the terms and conditions of the Creative Commons Attribution (CC BY) license (https:// creativecommons.org/licenses/by/ $4.0 /)$.

\begin{abstract}
Lactobacilli and bifidobacteria are an important part of human gut microbiota. Among numerous benefits, their antioxidant properties are attracting more and more attention. Multiple in vivo and in vitro studies have demonstrated that lactobacilli and bifidobacteria, along with their cellular components, possess excellent antioxidant capacity, which provides a certain degree of protection to the human body against diseases associated with oxidative stress. Recently, lactobacilli and bifidobacteria have begun to be considered as a new source of natural antioxidants. This review summarizes the current state of research on various antioxidant properties of lactobacilli and bifidobacteria. Special emphasis is given to the mechanisms of antioxidant activity of these bacteria in the human gut microbiota, which involve bacterial cell components and metabolites. This review is also dedicated to the genes involved in the antioxidant properties of lactobacilli and bifidobacteria strains as indicators of their antioxidant potential in human gut microbiota. Identification of the antioxidant biomarkers of the gut microbiota is of great importance both for creating diagnostic systems for assessing oxidative stress and for choosing strategies aimed at restoring the normal functioning of the microbiota and, through it, restoring human health. In this review, the practical application of probiotic strains with proven antioxidant properties to prevent oxidative stress is also considered.
\end{abstract}

Keywords: lactobacilli; bifidobacteria; probiotic; oxidative stress; antioxidant; gut microbiota

\section{Introduction}

Oxidative stress (OS) is a common pathogenetic mechanism of tissue damage, and is one of the main factors affecting the course of many diseases. OS is caused by the main reactive oxygen species (ROS): superoxide radicals, hydroxyl radicals $(\mathrm{HO} \cdot)$, lipid peroxide radicals (LOO·), and hydrogen peroxide $\left(\mathrm{H}_{2} \mathrm{O}_{2}\right)$. Endogenous $\mathrm{ROS}$ are a byproduct of metabolism that occurs naturally inside the cell during oxygen metabolism as a part of cellular respiration carried out by the mitochondria-free oxidation (FRO) of biomolecules, including proteins, lipids, and nucleic acids [1-3]. Exogenous ROS are the result of many negative external factors: environmental pollution, radiation, drugs, bacterial infection, excessive iron intake, imbalance in the intestinal microbiota, etc. [1,4]. In order to neutralize the pro-oxidants, the human body synthesizes antioxidant (AO) enzymes and molecules that form a natural biological AO barrier. AOs interact with free radicals generated in cells, and prevent the chain reactions caused by active oxygen species from disrupting cell functions. However, when the membranes and mitochondria are damaged, the amount of ROS increases dramatically. OS is defined as a condition in which the pro-oxidant-antioxidant balance in the cell is disturbed, resulting in DNA hydroxylation, protein denaturation, lipid peroxidation, and apoptosis, ultimately compromising cells' viability. OS is accompanied by various inflammatory processes, and is involved in a large variety of disorders, 
including many chronic conditions, such as cardiovascular, respiratory, neurological, and inflammatory diseases $[1,5]$.

Oxidative damage is a critical cause of inflammation, as well as age-related diseases. Age-related inflammation is described as a chronic, slow, systemic proinflammatory condition characterized by elevated levels of cytokines and inflammatory mediators. This type of inflammation lies at the heart of a wide range of age-related pathologies, including atherosclerosis, cancer, emphysema, liver cirrhosis, arthritis, neurodegenerative and cardiovascular diseases, chronic obstructive pulmonary disease, chronic kidney disease, etc. [1,5]. Chronic lung diseases, including those provoked by infectious and toxic agents, develop as a result of excessive amounts of ROS formed following chronic activation of the immune system [6]. OS and oxidative modification of proteins are common features of almost all cardiovascular pathologies, including myocardial infarction, stroke, and peripheral vascular diseases [7]. Reperfusion induces tissue reactions that fuel the production of ROS, sequestration of proinflammatory immunocytes in ischemic tissues, endoplasmic reticulum stress, and the development of postischemic capillary "no-reflow", which exacerbate tissue damage. Thus, OS is one of the most important pathological mechanisms of reperfusion injury, which causes apoptosis, autophagy, inflammation, and other tissue damage in several ways, ultimately causing irreversible damage to organs [8-10]. Ischemic/reperfusion injury is the most common cause of disease and death, and is a widespread problem in organ transplantation [11,12].

OS also contributes to and accompanies the development of neurodegenerative diseases. The central nervous system consists of some of the most metabolically active tissues of the body. Consumption of large amounts of oxygen by brain cells inevitably leads to the formation of a large number of its active forms. Nerve tissue is particularly sensitive to OS, which is associated with the peculiar properties of neuronal metabolism, mitochondrial dysfunction, and neuroinflammation caused by the activation of microglia, astrocytes, and other brain cells in response to the presence of various antigens, including microbial agents [13]. OS serves as a trigger for neurodegenerative brain diseases, such as Parkinson's disease, Alzheimer's disease, amyotrophic lateral sclerosis, and others [14]. In addition, neurodegenerative disorders are associated with the intestinal microbiota, which engage in a bidirectional communication as part of the gut-brain axis $[15,16]$. OS is also a major cause of depression $[17,18]$. Some studies suggest that depression is the clinical expression of activated immune-inflammatory, oxidative, and nitrosative stress pathways, including tryptophan catabolites, accompanying autoimmune reactions and increased bacterial translocation [19]. One of the possible biochemical mechanisms underlying the development of depression is the deregulation of the kynurenine pathway as a result of an increase in proinflammatory cytokine levels and the development of OS. These factors lead to a deficiency of serotonin and melatonin, which is considered to be one of the main causes of depression [20]. Increased inflammation and OS have been identified repeatedly in depression [21-23].

Considering the central role played by OS in many diseases, there is an urgent need to find novel solutions. The use of probiotics is being considered for the reduction of OS in the human body. Lactobacilli and bifidobacteria constitute an important probiotic component of the gut microbiota. They improve epithelial and mucosal barrier functions, regulate the composition of intestinal microbiota, and inhibit excessive proliferation of harmful bacteria [24]. Multiple in vivo and in vitro studies have demonstrated that lactobacilli and bifidobacteria possess excellent $\mathrm{AO}$ capacity, providing a certain degree of protection against oxidative stress $[25,26]$. Recently, lactobacilli and bifidobacteria have been considered as a new source of natural AOs. The ability of probiotic bacteria to produce AO enzymes and metabolites makes them the most promising of all means against the free radicals. New perspectives emerge when lactobacilli and bifidobacteria are used not in the form of live cultures of probiotic bacteria, but in the form of postbiotics-metabolites and cell components with antioxidant activity [27]. 
Lactobacilli and bifidobacteria, as regular inhabitants of the gastrointestinal tract (GIT) in both humans and animals, can exert $\mathrm{AO}$ activity via various mechanisms: chelation of toxic ions $\left(\mathrm{Fe}^{2+}\right.$ and $\left.\mathrm{Cu}^{2+}\right)$; synthesis of $\mathrm{AO}$ enzymes, peptides, and thiols; compounds with AO properties; effects on cell receptors and regulation of internal signal transduction systems of eukaryotic cells; activation of transcription of enzymes that neutralize free radicals; modulation of species composition of the gut microbiota; and impact on the permeability of the intestinal barrier [28,29].

Many recently published reviews describe the AO properties of lactobacilli and bifidobacteria, along with the mechanisms and signaling pathways employed by them to prevent oxidative damage. Moreover, the genes associated with lactobacilli and bifidobacteria redox potential, as well assuitable methods to evaluate bacteria's AO capacity, are being actively discussed [29-31]. This review considers the biomarkers of the AO potential of human gut probiotic lactobacilli and bifidobacteria, and their practical application, for the prevention of OS. Its main goal is to summarize the current state of the research on $\mathrm{AO}$ compounds derived from lactobacilli and bifidobacteria. Special emphasis is given to the mechanisms of $\mathrm{AO}$ activity used by probiotic lactobacilli and bifidobacteria, as well as their metabolites in the human gut. The AO properties of lactobacilli, bifidobacteria, and their components have been shown in multiple in vivo and in vitro studies. This review scrutinizes the known functional AO enzymes, metabolites, and cellular compounds of lactobacilli and bifidobacteria strains for a better understanding of their role in protecting the host and its own cells from OS. The genes encoding these AOs can be selected and used for carrying out metagenomic analysis of the gut microbiota, and to identify biomarkers of the AO potential of probiotic bacteria in various diseases accompanied by OS. The identification of AO biomarkers of probiotic bacteria is of great importance both for creating diagnostic systems for identifying OS, and for choosing strategies aimed at restoring normal functioning of the microbiota and restoring human health.

\section{Lactobacilli and Bifidobacteria as Members of the Human Gut Microbiota}

The gut microbiota plays a vital role in human health and pathology, and accordingly is a popular area of scientific research [32]. Bifidobacteria [33,34] and lactobacilli [35] are the most important probiotic bacteria of the gut microbiota. Their positive functions include antagonism and competition to opportunistic pathogens, improving digestion, participation in maturation of the immune system in early life and preservation of immune homeostasis during life, neuromodulation, and production of vitamins and other beneficial compounds, including AOs [36,37]. These bacteria can exhibit substantial AO activity in the host intestine, and promote the production of $\mathrm{AO}$ enzymes and compounds that act by neutralizing ROS and prevent oxidative damage $[6,12]$. However, most of their functions are strain-specific and not common to multiple genera or species [6,12,13].

The genus Bifidobacterium is one of the predominant bacterial populations in human gut microbiota. The abundance of bifidobacteria in vaginally delivered breast-fed infants amounts to $90 \%$ of the total gut microbiota. During life, the bifidobacterial count in the colon of adults drops to 5\%, and decreases even further in elderly people [36]. Many studies show that the abundance of bifidobacteria is lower in the gut microbiota of patients with various disorders, such as inflammatory bowel diseases, autism spectrum disorders (ASD), depression, and others [38,39].

Bifidobacteria play a major role in maintaining a healthy human gut microbiome $[36,40]$. One important function of the bifidobacterial genus is the production of acetate and lactate after carbohydrate fermentation, which can be converted into butyrate by other colonic bacteria through cross-feeding [41].

The species Bifidobacterium adolescentis, Bifidobacterium longum subsp. longum (B. longum), Bifidobacterium longum subsp. infantis (B. infantis), Bifidobacterium pseudolongum, Bifidobacterium catenulatum, Bifidobacterium pseudocatenulatum, Bifidobacterium breve, Bifidobacterium bifidum, Bifidobacterium animalis subsp. lactis (B. lactis), Bifidobacterium dentium, and Bifidobacterium angulatum are isolated from stool samples of healthy humans [40]. 
Bifidobacteria are anaerobes that colonize anoxic environments such as that of the colon, but their sensitivity to oxygen has been shown to vary between different species. For instance, B. lactis is considered oxygen-tolerant, while B. bifidum, B. breve, and B. longum are oxygen-sensitive (grow in the presence of $5 \% \mathrm{O}_{2}$ in liquid culture), and $B$. infantis and B. adolescentis are oxygen-hypersensitive (growth inhibited in 5\% $\mathrm{O}_{2}$ conditions) [42].

Lactobacilli are Gram-positive microorganisms incapable of spore formation. They are isolated from plants and plant products, silage, dairy products and milk, fermented food products (cheese, olives, pickles, salami, etc.), the oral cavity, and the vagina and the gut of humans and animals, as well as from household and industrial waste. Lactobacilli are divided into free-living, host-adapted, and "nomadic" species. Nomadic species are not autochthonous in the classical sense, but they are adapted to the ecosystems of the GIT and oral cavity, which allows them to survive there for a long time [43]. In adult feces, lactobacilli account only for $0.01-0.06 \%\left(10^{5}\right.$ to $\left.10^{8} \mathrm{CFU} / \mathrm{g}\right)$ of all bacterial species. Despite constituting an insignificant part of the gut microbiota, lactobacilli are a permanent and essential component. The predominant indigenous Lactobacillus species are Lactobacillus gasseri, Limosilactobacillus reuteri, Lactobacillus crispatus, Ligilactobacillus salivarius, and Ligilactobacillus ruminis. Gut-dwelling lactobacilli encompass Lactocaseibacillus casei, Limosilactobacillus plantarum, Limosilactobacillus fermentum, and Lactocaseibacillus rhamnosus. The most common isolates from the stomach mucosa are Limosilactobacillus antri, Limosilactobacillus gastricus, Lactobacillus kalixensis, L. reuteri, and Lactobacillus ultunensis. The species L. crispatus, L. gasseri, Lactobacillus jensenii, Limosilactobacillus vaginalis, and Lactobacillus iners are frequently found in the vagina [44]. A thorough study, using whole-genome sequencing, identified 86 Lactobacillus strains belonging to 52 species in human feces; 43 of those species occupied the GIT as permanent residents [45].

Lactobacilli are facultative anaerobes or microaerophiles. It has been demonstrated that some strains are able to use oxygen as a substrate in reactions mediated by flavin oxidases and, in some cases, to synthesize a minimal respiratory chain. The occurrence of genes related to aerobic (oxygen) and respiratory (oxygen, exogenous heme, and menaquinone to activate a minimal electron transport chain) metabolism correlates with the taxonomic classification of lactobacilli. Aerobic and respiratory metabolism was reported in L. casei, L. plantarum, Lactobacillus johnsonii, Lentilactobacillus buchneri, and L. reuteri. The shift from anaerobic growth to aerobic and/or respiratory offers physiological advantages, and affects the metabolite profiles of several species. Despite the fact that these differences do not necessarily result in increases in biomass production or growth rate, the cells grown in these conditions exhibit frequently improved tolerance to heat and OS [46].

OS contributes significantly to dysbiosis by reducing the microbial diversity of the gut microbiota $[47,48]$. The gut microbiota can regulate redox signaling and redox homeostasis in the host [49]. Lactobacilli and bifidobacteria, as regular inhabitants of the GIT of both humans and animals, can regulate the composition of the intestinal microbiota and inhibit excessive proliferation of harmful bacteria, which may contribute to decreasing OS.

Lactobacilli and bifidobacteria can reduce the intestinal $\mathrm{pH}$ and suppress the growth of various pathogenic bacteria to maintain the balance of the gut microbiota [50]. Additionally, some strains of lactobacilli and bifidobacteria produce a variety of substances toxic to pathogenic microorganisms, such as organic acids, bacteriocins, and biosurfactants [51]. Lactobacilli and bifidobacteria compete with pathogens for nutrients and adhesion to intestinal epithelial cells. The collagen surface-binding protein produced by L. fermentum RC-14 inhibits the adhesion of Enterococcus faecalis 1131 to epithelial cells [52]. Dietary alteration of the gut microbiota is strongly linked to OS. Mice fed a high-fat diet and treated with lipoic acid displayed decreased ROS levels and increased total AO capacity, which were positively associated with lactobacilli and negatively correlated with Escherichia coli and enterococci. Supplementation of L. johnsonii BS15 alleviated high-fat diet-induced OS and altered the intestinal Firmicutes/Bacteroidetes ratio in mice, suggesting that modulation of the gut microbiota by lactobacilli has the potential to improve the host redox state [30]. Probiotic lactobacilli and bifidobacteria are able to change the composition of the intestinal 
microbiota, tipping the balance towards a higher abundance of useful bacteria. A probiotic formulation comprising L. rhamnosus GG, L. acidophilus, L. plantarum, L. paracasei, and Lactobacillus delbrueckii increased the content of bacteria such as Prevotella and Oscillibacter, displaying anti-inflammatory activity in the gut microbiota of rats [53]. The consumption of B. longum BB536 altered the gut luminal biotin content and butyrate metabolism by changing the gut microbiota composition [54]. Wang et al. examined the AO activity of the strain B. bifidum ATCC 29521 - a species typical of the colonic microflora of humans-in the intestinal tracts of mice, by evaluating changes in the gut microbiota composition and ROS levels in their intestinal contents for 28 days of oral administration. B. bifidum ATCC 29521 significantly $(p<0.05)$ improved the ecosystem of the intestinal tract of BALB/c mice by increasing the amount of probiotic bacteria and by reducing unwanted bacterial populations [55].

\section{In Vitro and In Vivo Study of Antioxidant Properties of Lactobacilli and Bifidobacteria}

The AO properties of intact cells of lactobacilli and bifidobacteria, as well as their cellfree extracts (supernatants), intracellular extracts, metabolites, and cell wall components, have been demonstrated in both in vitro and in vivo studies (Table 1 ).

The main assays commonly used in in vitro studies are DPPH radical scavenging, the cellular antioxidant activity (CAA) assay, inhibition of linoleic acid peroxidation (ILAP), hydroxyl radical scavenging (HRS), and reducing power (RP) assays, among others. In the study of Amaretti et al. [28], the strains Levilactobacillus brevis, L. acidophilus, and $B$. lactis were selected as those displaying the highest levels of AO activity. Oxygen radical absorbance capacity (ORAC) was found to be a highly strain-specific feature characteristic of B. longum CUETM 172 [56]. Another study [57] investigated the AO effects of intracellular extracts and intact cells of L. acidophilus ATCC 4356 and B. longum ATCC 15708. Both experiments attested to a strong AO capacity of these strains. Proteins isolated from Bifidobacterium animalis subsp. animalis 01 were shown to possess AO activity [58]. The AO potential of supernatants, intact cells, and the intracellular extract of B. animalis 01 was also evaluated in the study of Chen et al. [59]. Lin and Yen [60] revealed in their studies the inhibitory effect of $B$. longum strains on lipid peroxidation. The AO action of cell-free culture supernatants of different Lactobacillus strains was evaluated using a test system based on Escherichia coli MG1655 strains carrying plasmids encoding luminescent proteins. The majority of strains (51 out of 81 ) belonging to six different species demonstrated high levels of AO activity [61].

The ability of probiotic bacteria and their metabolites to inhibit the increase in intracellular ROS has been shown in cellular models $[62,63]$. Some probiotic bacteria can upregulate the intracellular activity of superoxide dismutase (SOD), catalase (CAT), and glutathione peroxidase (GSH-PX) at both the enzymatic and transcriptional levels, and protect the cells from oxidative damage [64]. Pre-incubation with supernatants of B. longum CCFM752, L. plantarum CCFM1149, or L. plantarum CCFM10 significantly suppressed the angiotensin-II-induced increase in ROS levels and increased CAT activity in A7R5 cells, whereas CCFM752 inhibited NADPH oxidase activation, and CCFM1149 enhanced the intracellular SOD activity simultaneously. The supernatant of CCFM752 down regulated the expression of NADPH oxidase activator 1 (Noxa1) and angiotensinogen in A7R5 cells [65]. A study by Choi et al. on HT-29 cells revealed that both polysaccharides and heat-killed L. acidophilus 606 demonstrated high AO activities [66].

The antioxidative properties of Lactobacillus and Bifidobacterium strains have been demonstrated in different animal models. L. plantarum KSFY02 and B. animalis RH demonstrated $\mathrm{AO}$ properties in aged mice. Both strains were found to increase the activities of SOD, CAT, and GSH-PX in this model [67]. The strain L. brevis MG000874 was tested on a murine model of D-galactose-induced OS. Animals fed with probiotic bacteria had an increased amount of AO enzymes in all tissues, including glutathione-S-transferase in the liver and blood [68]. In a study by Wanchao using a model of ischemia and reperfusion shock of the brain in Sprague Dawley rats, it was shown that the administration of an 
inactivated culture of a Lactobacillus strain significantly improved neurological parameters, reduced the size of the affected area, reduced the amount of malondialdehyde (MDA), and increased the activity of SOD [69]. Tang et al. investigated the effects of the L. reuteri DSM 17938 on the development of OS in a model of necrotic enterocolitis in newborn mice. L. reuteri DSM 17938 reduced pathological parameters such as the expression of TNF- $\alpha$ and IL-1 $\beta$, MDA, GSSG, and the GSSG/GSH ratio, and significantly increased SOD activity and GSH levels in mice [70]. The introduction of L. brevis $47 \mathrm{f}$ strain to BALB/c mice subjected to 5-fluorouracil (5-FU)-induced mucositis protected enterocytes and decreased MDA blood plasma levels and MDA levels in the intestinal tissues (2-3 times lower than in the positive control group) [71]. The positive AO impact of L. fermentum U-21 strain on paraquat-treated C57/BL6 mice was observed in the study of Marsova et al. [72].

Grompone et al. carried out an interesting experiment, the purpose of which was to assess the AO potential of probiotic bacteria in Caenorhabditis elegans [73]. In total, 78 strains of Bifidobacterium and Lactobacillus were examined in the study. One of the most efficient strains was L. rhamnosus CNCM I-3690, which protected C. elegans from $\mathrm{H}_{2} \mathrm{O}_{2}$-induced OS, increasing their viability by $30 \%$ and increasing the average lifespan of worms by $20 \%$ [73]. The impact of 86 strains of Lactobacillus on the survival rate of C. elegans exposed to the oxidant paraquat was studied by Marsova et al. The screening yielded several promising strains possessing high $\mathrm{AO}$ activity [61].

The effects of intake of probiotic strains on the reduction in OS and the improvement of AO biomarkers has been investigated in interventional studies [74,75]. A meta-analysis conducted by Heshmati at al. studied the effects of consumption of probiotics and synbiotics on indicators of OS in healthy subjects. The authors concluded that these supplements improve $\mathrm{AO}$ resistance and increase the amount of $\mathrm{AO}$ enzymes in the human body [76]. Another meta-analysis conducted on patients with chronic kidney disease indicated that bacterial therapy has significant beneficial effects on serum levels of $\mathrm{C}$-reactive protein (CRP), total GSH, MDA, and total AO capacity [77]. A randomized clinical trial conducted by Chamari et al. investigated the impact of probiotics on the CAT plasma levels of healthy women [78]. The probiotic group demonstrated a significant increase in CAT activity in comparison with the untreated control group. The influence of intake of a probiotic containing the strains B. longum CECT 7347, L. casei CECT 9104, and L. rhamnosus CECT 8361 on OS induced by physical exercise (high intensity and duration) was studied in healthy subjects (male cyclists) [79]. Probiotic supplementation contributed to increased plasma AO levels and ROS neutralization.

Many studies have proven that strains of lactobacilli and bifidobacteria, along with their metabolites and cellular components, are capable of reducing OS in the host cells. While the AO activity of probiotic bacteria is not completely understood, some mechanisms have been described in published papers and reviews. 
Table 1. Examples of the study of AO activity of lactobacilli and bifidobacteria.

\begin{tabular}{|c|c|c|c|c|c|c|c|c|}
\hline $\begin{array}{l}\text { Strain and Species } \\
\text { of Bacteria }\end{array}$ & $\begin{array}{c}\text { The Investigated } \\
\text { Component } \\
\text { of Bacteria }\end{array}$ & $\begin{array}{l}\text { Experiment } \\
\text { Duration }\end{array}$ & Cell Lines & Animal Model & $\begin{array}{l}\text { Studed Group } \\
\text { of People }\end{array}$ & Tests Used & Research Results & References \\
\hline B. animalis 01 & $\begin{array}{c}\text { Intact cells, } \\
\text { culture } \\
\text { supernatant, } \\
\text { intracellular cell-free } \\
\text { extracts }\end{array}$ & & & & & $\begin{array}{l}\text { Inhibition of linoleic acid } \\
\text { peroxidation. } \\
\text { Scavenge DPPH; } \\
\text { scavenging effect on } \\
\text { hydroxyl radicals and } \\
\text { superoxide anions. }\end{array}$ & $\begin{array}{l}\text { All investigated probiotic forms } \\
\text { had AO activity. }\end{array}$ & [59] \\
\hline $\begin{array}{l}81 \text { Lactobacilli } \\
\text { strains of } 6 \\
\text { different species }\end{array}$ & $\begin{array}{l}\text { Cell-free } \\
\text { culture supernatant }\end{array}$ & & & & & $\begin{array}{l}\text { Test system based on E. coli } \\
\text { MG1655 strains } \\
\text { carrying plasmids } \\
\text { encoding luminescent } \\
\text { biosensors pSoxS-lux } \\
\text { and pKatG-lux. }\end{array}$ & $\begin{array}{c}51 \text { strains demonstrated } \\
\text { AO activity, }\end{array}$ & [61] \\
\hline $\begin{array}{l}\text { B. longum CCFM752, } \\
\text { L. plantarum } \\
\text { CCFM1149, } \\
\text { L. plantarum CCFM10 }\end{array}$ & $\begin{array}{l}\text { Cell-free culture } \\
\text { supernatant }\end{array}$ & & A7R5 & & & $\begin{array}{l}\text { Determination of the } \\
\text { angiotensin-II-induced } \\
\text { ROS levels, catalase } \\
\text { NADPH oxidase, and } \\
\text { intracellular superoxide } \\
\text { dismutase (SOD) activity. } \\
\text { Regulation of the } \\
\text { expression of NADPH } \\
\text { oxidase activator } \\
1 \text { (Noxa1) and } \\
\text { angiotensinogen. }\end{array}$ & $\begin{array}{c}\text { Suppression of the } \\
\text { angiotensin-II-induced increases in } \\
\text { ROS levels (all three strains); } \\
\text { Inhibition of NADPH } \\
\text { oxidase activation } \\
\text { (B. longum CCFM752, } \\
\text { L. plantarum CCFM1149); } \\
\text { Enhancement of the intracellular } \\
\text { SOD activity } \\
\text { (L. plantarum CCFM1149); } \\
\text { Downregulation of the expression } \\
\text { of NADPH oxidase activator } 1 \\
\text { (Noxa1) and angiotensinogen } \\
\text { (B. longum CCFM752). }\end{array}$ & [65] \\
\hline $\begin{array}{c}\text { L. acidophilus } \\
\text { ATCC 43121, } \\
\text { L. acidophilus } \\
\text { ATCC 4356, } \\
\text { L. acidophilus 606, } \\
\text { L. brevis ATCC 8287, } \\
\text { L. casei YIT 9029, } \\
\text { L. casei ATCC 393, } \\
\text { L. rhamnosus GG }\end{array}$ & $\begin{array}{l}\text { Heat-killed cell (HK); } \\
\text { the soluble } \\
\text { polysaccharides (SP) } \\
\text { components of } \\
\text { bacterial cells }\end{array}$ & & $\begin{array}{c}\text { Cancer cell lines } \\
\text { HT-29, HeLa, } \\
\text { MCF-7, U-87, } \\
\text { HepG-2, U2Os, } \\
\text { PANC-1, hEF }\end{array}$ & & & $\begin{array}{l}\text { Antiproliferative effects on } \\
\text { the cancer cells. } \\
\text { Induction of apoptosis. } \\
\text { Scavenging activity of the } \\
\text { DPPH free radicals. }\end{array}$ & $\begin{array}{l}\text { HK of L. acidophilus } 606 \text { and } \\
\text { L. casei ATCC } 393 \text { exhibited the } \\
\text { most profound inhibitory activity } \\
\text { in the all of tested cell lines; } \\
\text { SP of L. acidophilus } 606 \text { evidenced } \\
\text { the effective } \\
\text { anticancer activity. }\end{array}$ & [66] \\
\hline
\end{tabular}


Table 1. Cont.

\begin{tabular}{|c|c|c|c|c|c|c|c|c|}
\hline $\begin{array}{c}\text { Strain and Species } \\
\text { of Bacteria }\end{array}$ & $\begin{array}{c}\text { The Investigated } \\
\text { Component } \\
\text { of Bacteria }\end{array}$ & $\begin{array}{l}\text { Experiment } \\
\text { Duration }\end{array}$ & Cell Lines & Animal Model & $\begin{array}{l}\text { Studed Group } \\
\text { of People }\end{array}$ & Tests Used & Research Results & References \\
\hline L. brevis MG000874 & $\begin{array}{c}\text { Intact cells, } \\
\text { intracellular cell-free } \\
\text { extract }\end{array}$ & 8 weeks & & $\begin{array}{l}\text { Albino mice } \\
\text { exposed to } \\
\text { D-galactose- } \\
\text { induced OS }\end{array}$ & & $\begin{array}{l}\text { AO enzymes were } \\
\text { quantified in liver, } \\
\text { kidney, and serum } \\
\text { of animals. }\end{array}$ & $\begin{array}{l}\text { The treated animals } \\
\text { displayed improvement in SOD, } \\
\text { CAT, and GST in all tissues, as well } \\
\text { as GSH in the liver and serum. }\end{array}$ & [68] \\
\hline L. fermentum U-21 & Intact cells & $\begin{array}{l}\text { C. elegans } \\
\text { (1-2 days); mice } \\
\text { (23 days) }\end{array}$ & & $\begin{array}{l}\text { C57/BL6 mice, } \\
\text { C. elegans } \\
\text { exposed to } \\
\text { paraquat- } \\
\text { induced OS }\end{array}$ & & $\begin{array}{l}\text { The impact on the life span } \\
\text { of C. elegans; } \\
\text { A murine model of } \\
\text { Parkinson's disease }\end{array}$ & $\begin{array}{l}\text { The lifespan of the } \\
\text { C. elegans was extended by } 25 \% \text {. } \\
\text { L. fermentum U- } 21 \text { ensured normal } \\
\text { coordination of movements and the } \\
\text { safety of dopaminergic neurons in } \\
\text { the brain. }\end{array}$ & [72] \\
\hline $\begin{array}{l}\text { L. plantarum A7 } \\
\text { (KC 355240, LA7) }\end{array}$ & $\begin{array}{l}\text { Probiotic soy milk, } \\
200 \mathrm{~mL} / \text { day }\end{array}$ & 8 weeks & & & $\begin{array}{c}24 \text { type } \\
2 \text { diabetic } \\
\text { kidney disease } \\
\text { patients }\end{array}$ & $\begin{array}{c}\text { Malondialdehyde, } \\
\text { 8-iso-prostaglandin } \\
\text { F2a, oxidized } \\
\text { glutathione, total } \\
\text { antioxidant capacity (TAC), } \\
\text { reduced glutathione (GSH), } \\
\text { glutathione peroxidase, } \\
\text { and glutathione reductase } \\
\text { were measured in } \\
\text { the serum. }\end{array}$ & $\begin{array}{c}\text { Oxidized } \\
\text { glutathione concentration was } \\
\text { significantly reduced; } \\
\text { the levels of GSH, } \\
\text { glutathione peroxidase, and } \\
\text { glutathione reductase were } \\
\text { significantly increased; } \\
\text { no significant reduction in the } \\
\text { 8-iso-prostaglandin F2 } \alpha, \\
\text { malondialdehyde and no induction } \\
\text { of TAC were detected. }\end{array}$ & [75] \\
\hline $\begin{array}{l}\text { Various probiotics } \\
\text { and synbiotics }\end{array}$ & & & & & $\begin{array}{l}27 \text { articles that } \\
\text { included } \\
1363 \text { subjects } \\
\text { (709 cases and } \\
699 \text { controls) }\end{array}$ & $\begin{array}{l}\text { Total antioxidant capacity } \\
\text { (TAC), glutathione (GSH), } \\
\text { superoxide dismutase } \\
\text { (SOD), nitric oxide (NO), } \\
\text { andmalondialdehyde } \\
\text { (MDA) were taken } \\
\text { into account. }\end{array}$ & $\begin{array}{l}\text { TAC, GSH, SOD, and NO were } \\
\text { higher in probiotics } \\
\text { (or synbiotics) group } \\
\text { compared to controls. } \\
\text { MDA level was lower than controls. }\end{array}$ & [76] \\
\hline
\end{tabular}


Table 1. Cont.

\begin{tabular}{|c|c|c|c|c|c|c|c|c|}
\hline $\begin{array}{c}\text { Strain and Species } \\
\text { of Bacteria }\end{array}$ & $\begin{array}{c}\text { The Investigated } \\
\text { Component } \\
\text { of Bacteria }\end{array}$ & $\begin{array}{l}\text { Experiment } \\
\text { Duration }\end{array}$ & Cell Lines & Animal Model & $\begin{array}{l}\text { Studed Group } \\
\text { of People }\end{array}$ & Tests Used & Research Results & References \\
\hline $\begin{array}{l}\text { L. acidophilus, } \\
\text { L. casei, } \\
\text { B. bifidum }\end{array}$ & $\begin{array}{l}\text { Capsules with } \\
\text { intact cells } \\
\text { (Tak Gen Zist } \\
\text { Pharmaceutical } \\
\text { Company, } \\
\text { Tehran, Iran) }\end{array}$ & 12 weeks & & & $\begin{array}{c}\text { Diabetic } \\
\text { hemodialysis } \\
\text { patients, } 28 \text { cases } \\
\text { and } 27 \text { placebos. }\end{array}$ & $\begin{array}{c}\text { Plasma glucose, } \\
\text { serum insulin, } \\
\text { assessment-estimated } \\
\text { insulin resistance, } \\
\text { assessment-estimated } \\
\text { beta-cell } \\
\text { function and HbA1c, } \\
\text { insulin sensitivity, } \\
\text { serum C-reactive } \\
\text { protein, } \\
\text { plasma malondialdehyde, } \\
\text { total iron-binding } \\
\text { capacity, and } \\
\text { plasma total } \\
\text { antioxidant capacity } \\
\text { were determined. }\end{array}$ & $\begin{array}{c}\text { Patients who received } \\
\text { probiotic supplements } \\
\text { showed significantly } \\
\text { decreased plasma glucose, } \\
\text { serum insulin, } \\
\text { assessment-estimated } \\
\text { insulin resistance and } \\
\text { beta-cell function and HbA1c, } \\
\text { insulin sensitivity, serum } \\
\text { C-reactive protein, } \\
\text { plasma malondialdehyde, } \\
\text { and total iron-binding capacity. } \\
\text { Patients showed an increase in } \\
\text { plasma total antioxidant capacity. }\end{array}$ & [74] \\
\hline
\end{tabular}




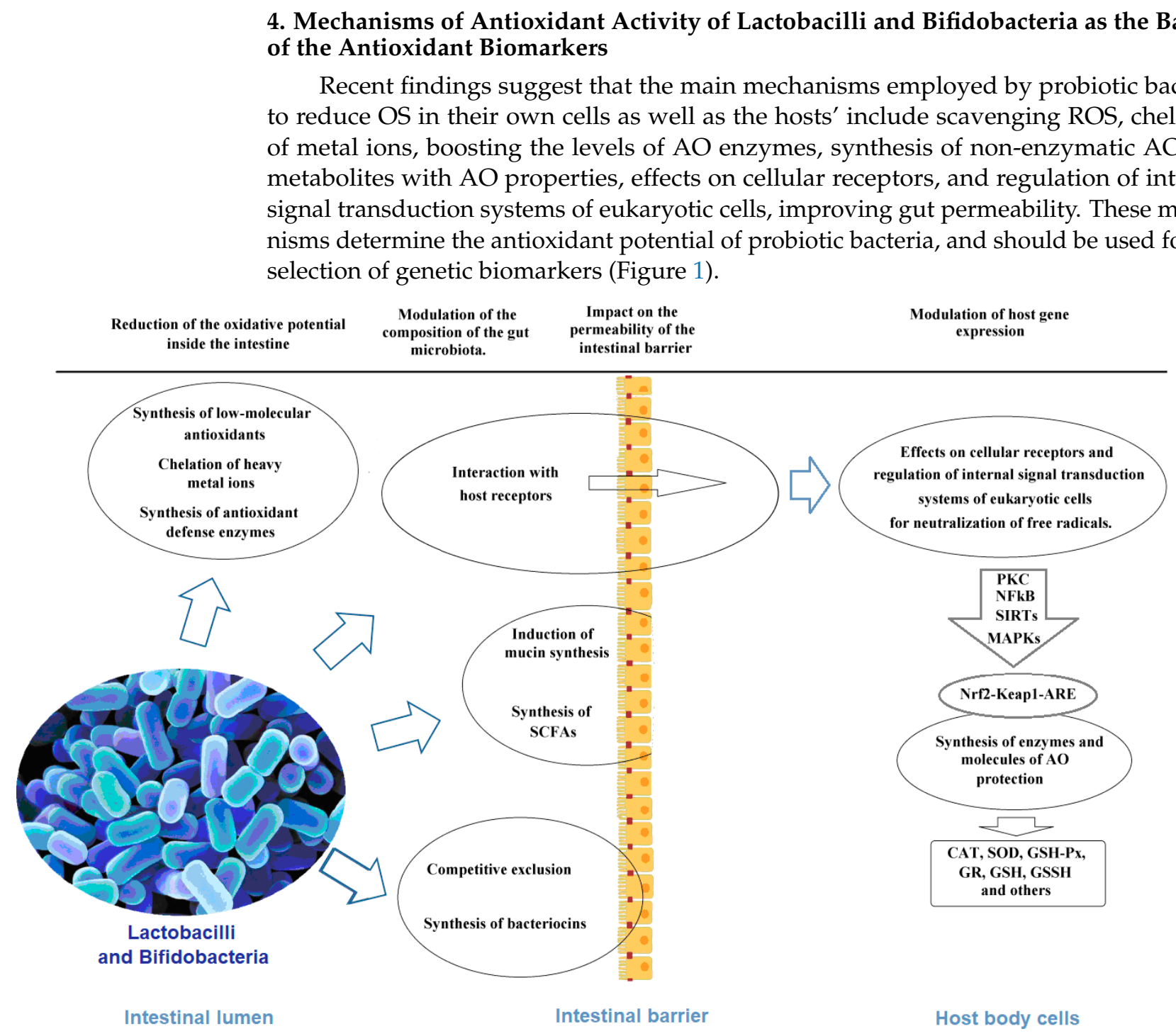

Figure 1. Mechanisms of antioxidant action of lactobacilli and bifidobacteria inside the intestine of the host.AO: antioxidant; OS: oxidative stress; SCFAs: short-chain fatty acids; NF-кB: nuclear factor kappa B, eukaryotic transcription factor; SIRTs: a family of NAD-dependent protein deacetylases; PKC: protein kinase C; MAPKs: mitogen-activated protein kinases; SOD: superoxide dismutase; CAT: catalase; GSH: reduced glutathione; GSSH: oxidized glutathione; GSH-Px: glutathione peroxidase; GR: glutathione reductase; NRF2-Keap-ARE: a signaling system responsible for the expression of antioxidantresponsive elements (ARE-genes).

\subsection{Chelation of Pro-Oxidative Metal Ions}

Metal ions are capable of initiating the decomposition of hydrogen peroxide into peroxyl and alkoxy radicals and triggering lipid peroxidation [80]. The chelating capacity of probiotic strains may be explained by the content of certain chelators that are normally detected in the intracellular cell-free extract of bacterial cells [29]. For instance, L. rhamnosus GG and L. paracasei Fn032 significantly inhibit the production of $\mathrm{H}_{2} \mathrm{O}_{2}$ induced by ferrous ions. L. casei KCTC 3260 also possesses a high AO ability via chelating $\mathrm{Fe}^{2+}$ or $\mathrm{Cu}^{2+}$ [81].

DNA-binding ferritin-like protein (Dps), found in the strain B. longum NCC2705, contains conserved iron-binding sites that can carry out chelation of metal ions [82]. Dps proteins are widespread among lactobacilli [83]. One gene encoding a ferroxidase, which was shown to participate in iron chelation, was found in the genome of B. longum NCC2705 [84]. The HprA1 protein derived from $L$. casei confers resistance to $\mathrm{H}_{2} \mathrm{O}_{2}$; it binds to $\mathrm{Fe}^{2+}$ and prevents the formation of hydroxyl radicals [85]. The $\operatorname{cop} \mathrm{B}$ (export ATPase for copper ions) 
and $\operatorname{cop} \mathrm{R}$ (inductor-transcription factor) genes are also involved in the response to OS triggered by $\mathrm{H}_{2} \mathrm{O}_{2}$ in L. plantarum. It is assumed that these proteins are associated with the chelation of copper ions [86]. The chelating activity of lactobacilli and bifidobacteria is strain-specific [87].

\subsection{Synthesis of Antioxidant Enzymes}

$\mathrm{AO}$ enzymes, as a major part of the $\mathrm{AO}$ defense system, are deficient in obligate anaerobic bacteria such as bifidobacteria and lactobacilli.

Superoxide dismutase (SOD) is the most efficient enzyme capable of inactivating the superoxide anion. It decomposes the superoxide anion into molecular $\mathrm{O}_{2}$ and hydrogen peroxide $\left(\mathrm{H}_{2} \mathrm{O}_{2}\right)$ using $\mathrm{Zn} / \mathrm{Cu}, \mathrm{Fe} / \mathrm{Mn}$, and $\mathrm{Ni}$ as cofactors. MnSODs have been found in several species of lactobacilli, whereas FeSODs and $\mathrm{Cu} / \mathrm{ZnSODs}$ are not that common. It has been demonstrated that the activity of MnSODs is dependent on the intracellular concentration of $\mathrm{Mn}^{2+}$ [66]. Only a few species of lactobacilli-such as L. casei, L. paraplantarum, L. buchneri, L. sakei, and L. brevis - exhibit SOD activity. Interestingly, SOD activity was found to be absent from the strain L. casei Shirota [88]. The selection of promoters and multi-copy sod-expressing cassettes allowed the gene sod to be cloned from L. casei LC2W into S. thermophilus. The activity of the SOD enzyme was increased in the genetically modified strain, which was more resistant to $\mathrm{H}_{2} \mathrm{O}_{2}$ [89], proving that the sod gene of L. casei is active and plays a role in resistance to $\mathrm{H}_{2} \mathrm{O}_{2}$.

Catalase (CAT) is the enzyme that decomposes $\mathrm{H}_{2} \mathrm{O}_{2}$ into water and oxygen. CAT also oxidizes low-molecular alcohols and nitrites in the presence of $\mathrm{H}_{2} \mathrm{O}_{2}$. Although the majority of lactobacilli are CAT-negative, genes coding for catalases have been detected in a number of lactobacilli. CAT in lactobacilli contains a heme group or Mn (less frequently) as a prosthetic group $[46,90]$. An in silico analysis of 321 genomes of industrially relevant lactobacilli demonstrated that genes of heme-catalase were widespread among the L. brevis, L. plantarum, and L. sakei groups, while the Mn-catalase was present only in several strains such as L. casei and L. zeae [91]. L. casei N87 contains two CAT genes-heme- and Mn-typewhich are rare in lactobacilli [92]. L. brevis has been described as CAT-negative regardless of the fact that an endogenous heme-dependent CAT has been identified by heterologous expression in L. casei. Indeed, L. brevis cannot synthesize heme due to lack of the enzymes for protoporphyrin IX synthesis, and therefore loses its CAT activity. L. brevis catalase can be activated by exogenous gemin. Activated CAT provides protection against the toxicity of $\mathrm{H}_{2} \mathrm{O}_{2}$ [93]. It has been demonstrated that the activity of heme-CAT depends on concentration of hematin [94]. In lactobacilli, the evolution of heme-containing proteins is still poorly understood, and further studies are needed in order to determine whether the genes encoding heme-catalases, such as those encoding the cytochrome oxidase, have been horizontally acquired from aerobic donors, or whether they endured gene loss events [92].

So far, no genes encoding CAT and SOD have been annotated in databases of genome sequences of bifidobacteria [95].

The NADH oxidase/NADH peroxidase system (NOX/NPR) also prevents oxygen accumulation in bacterial cells by producing $\mathrm{H}_{2} \mathrm{O}_{2}$ via $\mathrm{NOX}$ and then reducing it to water via NPR. These $\mathrm{O}_{2}$-consuming enzymes are responsible for the rapid elimination of $\mathrm{O}_{2}$, and play an important role in maintaining the intracellular redox balance. The activity of the NOX/NPR system contributes to the maintenance of the NADH/NAD+ balance by promoting cofactor regeneration. The occurrence of nox genes is limited among lactobacilli. $\mathrm{H}_{2} \mathrm{O}$-forming $\mathrm{NOX}$ is widespread in the L. casei group (a single sequence is generally present), while some L. plantarum strains harbor multiple genes for the NOX (nox1, nox2, nox3, nox4, nox5, nox6). In L. plantarum WCFS1, NOX activity during aerobic growth is exclusively determined by the nox5 gene [96-98]. All L. plantarum strains harbor two NPRs (npr1, npr2), but some studies have revealed that only npr2 (1p_2544) is upregulated during aerobic growth [98]. In L. casei IGM394, the mechanism of $\mathrm{H}_{2} \mathrm{O}_{2}$ tolerance is solely dependent on NPR [96]. 
NOX and the oxygen-dependent coproporphyrinogen III oxidase are involved in the detoxification of molecular oxygen and/or $\mathrm{H}_{2} \mathrm{O}_{2}$ in B. animalis $[99,100]$. Other bifidobacteria display reduced NOX and NPR activities [101].

Thioredoxins (Trxs) are reductases that catalyze protein disulfide/dithiol conversion with a conserved -CGPC- active site motif. The Trxs and GSH-glutaredoxin systems play important roles in defense against OS by maintaining intracellular dithiol/disulfide homeostasis in both prokaryotic and eukaryotic cells. They are involved in transfer of electrons to thiol-dependent peroxidases, thereby maintaining redox homeostasis. The Trx system includes thioredoxin reductase, NADPH, thioredoxins, and thioredoxin peroxidase. The thioredoxin-dependent reduction system reduces a number of proteins, including peroxiredoxins, by directly reducing $\mathrm{H}_{2} \mathrm{O}_{2}$, scavenging hydroxyl radicals, quenching singlet oxygen, and maintaining the intracellular thiol-disulfide balance [102]. The thioredoxin system plays an essential role in DNA and protein repair by reducing ribonucleotide reductase and methionine sulfoxide reductases, and regulates the activity of numerous redox-sensitive transcription factors [103].

Peroxiredoxins are enzymes containing a redox-active cysteine site that are oxidized by the peroxide substrate. The recycling back to thiols is reduced by thioredoxin. In bacteria, peroxiredoxins are frequently referred to as alkyl hydroperoxide reductase (AhpC); other names are also used, such as thiol-specific antioxidant (TSA) or thioredoxin peroxidase (TPx). Many bacteria also express the flavoprotein AhpF, which acts as a disulfide reductase that recycles bacterial peroxiredoxins. Peroxiredoxins constitute an important component of the bacterial defense system against toxic peroxides. AhpC is localized in the cytoplasm, and has a wide substrate range that includes $\mathrm{H}_{2} \mathrm{O}_{2}$, organic peroxides, and peroxynitrite. This enzyme participates in the control of endogenous peroxides, as well as in the inducible defense response to exogenous peroxides or general stresses.

Transcriptomic analysis indicates that peroxiredoxins and thioredoxin reductase are potent defense systems against $\mathrm{H}_{2} \mathrm{O}_{2}$-induced stress in B. longum and B. lactis species [104]. This ability is determined by a gene encoding the AhpC subunit of alkyl hydroperoxide reductase, which reduces the content of $\mathrm{H}_{2} \mathrm{O}_{2}$ and protects cells from OS [105]. Alkyl hydroperoxide reductase is the main scavenger of endogenous $\mathrm{H}_{2} \mathrm{O}_{2}$ generated during aerobic cultivation of B. longum [106-108]. Sequencing of the genome of B. longum revealed the presence of the trl gene encoding thioredoxin reductase (NADPH) which, together with alkyl hydroperoxide reductase, is supposedly involved in the elimination of $\mathrm{H}_{2} \mathrm{O}_{2}$ and reduction of glutaredoxin $[75,77]$. The genomes of the strains B. longum LTBL16, B. longum NCC2705, and $B$. lactis were found to contain a gene encoding peroxiredoxin $Q / B C P$, which eliminates ROS $[104,107,109]$. The thioredoxin-dependent AO system might be the principal redox homeostasis system in the strain B. longum BBMN68, in which the gene encoding a thioredoxin reductase was highly upregulated after $60 \mathrm{~min}$ of exposure to oxygen [105].

The thioredoxin-thioredoxin reductase system is the major thiol/disulfide redox system in Lactobacillus strains, and genes encoding thioredoxin (TRX) and thioredoxin reductase (TR) are present in almost all sequenced strains. Global transcriptomic analyses revealed that, following exposure of L. plantarum CAUH2 to $\mathrm{H}_{2} \mathrm{O}_{2}$-induced stress, the expression of thioredoxin reductase increased 36.76-fold. Some transcriptional regulators (Spx, CcpA, and MarR1) were also predicted to be involved in the adaptive response to $\mathrm{H}_{2} \mathrm{O}_{2}$ [110]. In L. plantarum WCFS1, overexpression of the thioredoxin reductase gene $(\operatorname{tr} x \mathrm{~B} 1)$ resulted in a higher TR activity and an increased resistance to OS, which was accompanied by induced transcription of 16 genes associated with OS response. The authors suggested that thioredoxin reductase is a pivotal enzyme in the OS response in L. plantarum WCFS1 [111]. Normally, the genome of lactobacilli contains several thioredoxin genes, and their functions differ from one another. The $L$. casei Shirota strain possesses four putative thioredoxin genes and one putative thioredoxin reductase gene. Mutants in different $t r x$ genes show different properties and different reactions to the induction by $\mathrm{H}_{2} \mathrm{O}_{2}$ OS [112]. The trx and trxR genes may be localized on plasmids of lactobacilli [113]. The genomes 
of lactobacilli contain the peroxiredoxin gene $(a h p C)$ [114]; they also contain a $d s b$ A gene encoding a bacterial thiol disulfide oxidoreductase. DsbA catalyzes intrachain disulfide bond formation as peptides emerge into the cell's periplasm [113].

B. bifidum, which grows well under aerobic conditions, contains a homologue of b-type dihydroorotate dehydrogenase (DHOD) composed of PyrK (31 kDa) and PyrDb (34 kDa) subunits. The purified enzyme catalyzed a $\mathrm{H}_{2} \mathrm{O}_{2}$-forming $\mathrm{NADH}$ oxidase reaction in the presence of $\mathrm{O}_{2}$. It was suggested that the enzyme could be involved in $\mathrm{H}_{2} \mathrm{O}_{2}$ production in bifidobacteria in highly aerated environments [114].

Possible class I pyridine nucleotide disulfide oxidoreductase (PNDR) is involved in the cellular response to OS detected in the B. longum NCC 2705 and B. longum BBMN68 strains $[105,115]$. The genes encoding peroxide oxidoreductase (LTBL16-000027, LTBL16000028, and LTBL16-000976) and NADH oxidase (LTBL-001911) were identified in the genome of the B. longum LTBL16 strain, which can effectively eliminate ROS in bifidobacteria and increase resistance to oxygen [116].

The mentioned basic AO enzymes are widespread among lactobacilli and bifidobacteria, but other enzymes also exist. Unfortunately, many of these enzymes remain unidentified. Apart from AO enzymes, probiotic bacteria can produce non-enzymatic AOs.

\subsection{Non-Enzymatic Antioxidants}

Thiol compounds containing two cysteine molecules play an important role in AO protection conferred by lactobacilli and bifidobacteria; these are compounds of the glutathione and thioredoxin groups. Glutathione (GSH) is a tripeptide of gamma-glutamyl-cysteinylglycine, synthesized from amino acids. GSH is involved in maintaining the cellular redox status $[117,118]$. Genetic analysis shows that the first of the GSH synthesis genes-the gamma-glutamylcysteine synthetase gene (glutamate-cysteine ligase, $g s h \mathrm{~A}$ )—is found in many lactobacilli, while the second gene-alpha-L-glutamate ligase (gshB)-is absent. A number of bacteria - especially $S$. thermophilus - have a multidomain bifunctional fusion glutamate-cysteine ligase/glutathione synthetase gene ( $g s h \mathrm{AB}, g s h \mathrm{~F})$ encoding a protein of $\sim 700 \mathrm{AA}$, capable of performing both reactions. Lactobacilli also possess a similar protein (for example, GshAB of L. plantarum subsp. plantarum P-8, 751 AA); however, despite similarity in size and partial homology with Streptococcus proteins, it exhibits only glutamate-cysteine ligase function. These data indicate that lactobacilli are not capable of synthetizing GSH de novo. Whole genome sequences of 26 food-grade lactic acid bacteria (LAB) confirmed that all of the strains tested were incapable of GSH synthesis, but could import it from their environment [119]. However, when the gsfF genes from L. plantarum and $L$. casei were cloned and expressed in E. coli cells, GSH titers were enhanced significantly, demonstrating that putative GshF from Lactobacillus exert functional activity on GSH biosynthesis [120]. Lactobacilli import GSH from the growth medium by using the CysCD ABC transporter ATP-binding proteins [121]. Despite the inability to synthesize GSH, lactobacilli possess enzymes of glutathione metabolism: glutathione peroxidase reduces hydrogen peroxide with the participation of glutathione, glutathione reductase restores the disulfide bond of oxidized glutathione, and glutathione transferase performs glutathione attack on cellular toxic compounds, along with detoxification and xenobiotic degradation [122]. Upon $\mathrm{H}_{2} \mathrm{O}_{2}$-induced OS, the transcriptional activity of glutathione reductase gene increased by more than six times in L. plantarum, and the transcription of glutathione peroxidase also increased [123]. Killisaar et al. were the first to report that L. fermentum ME3 possesses a fully functional GSH system comprising both a GSH peroxidase and a GSH reductase [124]. Lactobacilli contain the genes for the synthesis of glutaredoxin-small redox enzymes oxidized by substrates, and reduced non-enzymatically by glutathione [125].

Most studied bifidobacteria do not produce any detectable amounts of GSH, but the gene for the protein with the prokaryotic glutathione synthetase domain, involved in the synthesis of glutathione, is located in the genome of the B. dentium JCVIHMP022 strain (BioCyc database). Most bifidobacteria contain the gene gsiA for glutathione import via 
the ATP-binding protein that is involved in the transport of glutathione from the growth medium into the cell.

The enzymes described above determine the resistance to OS in bacterial cells. They can be important biomarkers for the selection of bacteria with AO properties (Table 2).

\subsection{Other Probiotic Metabolites and Cellular Components with Antioxidant Properties}

Apart from the endogenous enzymatic and non-enzymatic AOs, bifidobacteria and lactobacilli can produce a number of metabolites and cellular components that can block free radical oxidation reactions.

Peptides derived from hydrolyzed food proteins have been shown to possess AO activities that can impart protection against the peroxidation of lipids and fatty acids [126]. It has been observed that peptic digestion of casein liberates small peptides with radical scavenging activity [127]. Increased AO activity of milk following fermentation with commonly used dairy starter cultures, including $L$. jensenii and L. acidophilus, has been observed [23,128].

Production of bioactive peptides with AO properties by bifidobacteria is rarely reported in the literature. One example is a study that demonstrated the possibility of antioxidant peptide production from bovine casein by B. longum [129]. The subtilisin-like serine protease cell envelope protease (CEP) that catalyzes the cleavage of peptide bonds could be used by B. longum KACC91563 for the production of bioactive peptides with AO properties [130].

The AO ability of probiotic bacteria can be considered to be a result of the ability to produce amino acids in high quantities. Bifidobacteria exhibit the ability to produce amino acids with AO properties, such as cysteine and methionine [131]. Some bifidobacteria possess the genes involved in the reverse transsulfuration pathway, which produces cysteine from methionine using homocysteine as an intermediate. There are genes such as ahcY that encode an $S$-adenosylhomocysteinase, and $l u x S$, which encodes a S-ribosylhomocysteinase for the $S$-adenosyl methionine cycle $[130,131]$.

Tryptophan metabolites elicit $\mathrm{AO}$ and anti-inflammatory immune responses partially via activation of the Nrf2-ARE pathway. These metabolites increase expression of target genes in the NF-E2-related factor 2 (NRF2)-mediated AO pathway (HMOX1, HS3ST2, TXNRD1, MGST1, ZNF643, EPS8, and TIPARP), and upregulate the AhR-inducible gene CYP1A1 [132]. L. reuteri and L. johnsonii convert tryptophan to indole-3-aldehyde, which exacerbates inflammatory disorders and affects the intestinal tract. Tryptophan acts as a metabolic substrate for the production of AhR ligands, such as indole-3-aldehyde and indole-3-lactic acid, by members of Lactobacillus, and these ligands inhibit colonization by Candida albicans and uncultivable segmented filamentous bacteria [133]. AO abilities have been identified for some tryptophan metabolites, such as $p$-hydroxyphenylacetate [134], indoleacrylic acid [132], and indolepropionic acid [88]. The enzymes tyramine dehydrogenase (hpa gene), indolelactate dehydratase (from gene cluster (fldAIBC)), and phenyllactate dehydratase (from gene cluster (fldAIBC)) could be used by bifidobacteria for the production of these metabolites [132].

Recent studies have revealed that histamine also plays a role in the AO potential of lactobacilli. Supernatants containing different concentrations of histamine produced by L. reuteri strains increased the activities of CAT and SOD, as well as the phagocytic activity of human leucocytes $[135,136]$.

Several studies have linked improvements in gut health with the increase in gastrointestinal AO capacity following intake of AOs such as polyphenols and tocopherols [137]. Polyphenols such as lignans and flavonoids-both products of fermentation of plant components by bifidobacteria-possess an AO effect $[138,139]$. In the study of Braune and Blaut, the ability of Bifidobacterium strains $(n=25)$ to produce lignan and flavonoids aglycones from flaxseed and soybean extracts were examined [140]. Most of the Bifidobacterium strains increased the concentrations of secoisolariciresinol, daidzein, genistein, naringenin, eriodyctiol, luteolin, and apigenin. Moreover, B. pseudocatenulatum and B. breve strains 
showed high production of herbacetin, increased the kaempferol concentration, and produced quercetin and quercetagetin. Bifidobacterium strains converted the glycosides of a wide range of flavonoids into their aglycones, increasing the $\mathrm{AO}$ activity and improving their bioavailability [141].

Individual strains such as L. acidophilus, L. buchneri, L. casei, and L. plantarum are capable of carrying out O-deglycosylation of flavonoids. The strain L. plantarum IFPL935 was able to perform deglycosylation of $C$-glycosides of flavonoids. The enzymes $\beta$-glucosidases and $\alpha$-rhamnosidases participate in this process. Some strains catalyze only single steps of known transformation pathways, while others catalyze complete conversion to typical degradation products [140]. The strain L. pentosus NGI01 produced high yields of hesperetin and quercetin from hesperidin and rutin, respectively [142].

Ferulic acid (FA) is a natural phenolic acid that is present in abundance in many types of foods-namely, cereals, fruits, and coffee. FA is a potent AO that can eliminate free radicals via neutralization reactions [143]. Some probiotic bacteria produce feruloyl esterase (FE), which hydrolyzes and releases FA from its bound state [144], thereby conferring health-beneficial AO properties. Based on qualitative precipitation and quantitative HPLC assays, L. fermentum NCIMB 5221 was found to produce the most active FE among several bacteria tested [145], and antioxidant capacity tests verified its significant AO activity. Oral administration of L. fermentum CRL1446 to mice increased total intestinal FE activity, decreased the basal percentage of plasma lipoperoxides, and increased glutathione reductase activity, thus improving oxidative status. Probiotic strains might secrete FE enzymes directly into the intestine, or via regulation of the intestinal microbiota stimulating FE activity [146].

Strains of B. longum use hydroxycinnamic acid esterase (gene caeA) to release hydroxycinnamates from plant-based dietary sources [141]. $\beta$-glucosidase is used by bifidobacteria to produce flavonoids and lignans from various plant sources $[137,138,147]$. Urolithin A (UroA) is a microbial metabolite derived from polyphenolics (e.g., ellagitannins/ellagic acid) of pomegranate and berries by dehydroxylase from urolithin C. UroA displays potent anti-inflammatory, antioxidative, and antiaging properties [148]. B. pseudocatenulatum INIA P815 can use up to 9 and 10 dehydroxylases to convert ellagic acid into UroA [149].

Some lactobacilli produce organic pigments called carotenoids, which are associated with AO activity. Lactiplantibacillus pentosus KCCP11226 harbors C30 carotenoid biosynthetic $(\operatorname{crt} \mathrm{M}, \operatorname{crt} \mathrm{N})$ genes, which are not common to most Lactobacillus species. This strain demonstrated the highest survival when exposed to OS, and the highest ability to scavenge DPPH free radicals. Carotenoid production in the strain was increased following exposure to $7 \mathrm{mM} \mathrm{H}_{2} \mathrm{O}_{2}$ [150].

Probiotic bacteria, as members of the gut microbiota, are capable of synthesizing vitamin $\mathrm{K}$ and most of the water-soluble $\mathrm{B}$ vitamins.

B. bifidum, $B$. breve, $B$. adolescentis, $B$. infantis, and $B$. longum produce the vitamins nicotinate, thiamine $\left(\mathrm{B}_{1}\right)$, pyridoxine $\left(\mathrm{B}_{6}\right)$, folate $\left(\mathrm{B}_{9}\right)$, and cobalamin $\left(\mathrm{B}_{12}\right)$ [147].

Folic acid $\left(\mathrm{B}_{9}\right)$ increases the resistance of lipoproteins to oxidation [151]. The pabC gene encoding 4-amino-4-deoxychorismate lyase for folate production was found in the genomes of B. adolescentis ATCC15703 and B. pseudocatenulatum [152]. Wild-type lactobacilli cannot synthesize folate. L. plantarum constitutes an exception among lactobacilli, since it is capable of folate production in the presence of para-aminobenzoic acid [153].

Vitamin $\mathrm{B}_{6}$ plays an important role in the mechanism of AO activity [147]. The synthase (pyridoxal $5^{\prime}$-phosphate synthase PdxS subunit) ( $p d x S$ gene) $5^{\prime}$-phosphate synthase PdxT subunit ( $p d x T$ gene) is involved in vitamin $\mathrm{B}_{6}$ production in bifidobacteria [152].

Cobalamin (vitamin $\mathrm{B}_{12}$ ) possesses $\mathrm{AO}$ properties [154]. The main producers of vitamin $B_{12}$ are $B$. animalis, $B$. infantis, and $B$. longum. The enzymes cobaltochelatase and adenosylcobyric acidsynthase are used to synthesize adenosylcobalamin [155]. Lactobacilli are traditionally known to beauxotrophic for cobalamin. However, individual strains of L. reuteri, L. fermentum, L. buchneri, Lentilactobacillus hilgardii, and L. brevis were able to 
synthesize cobalamin [156]. Approximately 30 genes participated in the de novo synthesis of vitamin $B_{12}$ [157].

Riboflavin participates in various redox reactions and energy utilization. The enzymatic activities required for the biosynthesis of riboflavin from guanosine triphosphate (GTP) and ribulose-5-phosphate are encoded by the genes $r i b \mathrm{G}, r i b \mathrm{~B}, r i b \mathrm{~A}, r i b \mathrm{H}$, and $r i b \mathrm{C}$. The ability to synthesize riboflavin has been shown in many lactobacilli: L. plantarum, L. fermentum, Limosilactobacillus mucosae, L. acidophilus, etc. The amount of synthesized riboflavin reached $2.36 \mathrm{mg} / \mathrm{L}$ or more, depending on the conditions of cultivation [158].

Vitamin K2 (menaquinone) is produced by bacteria in the intestine, and plays an important role in electron transport. There is one account of production of menaquinone by individual members of lactobacilli [159]. Production of vitamin K2 by L. fermentum LC272 reached $184.94 \mu \mathrm{g} / \mathrm{L}$ in Rogosa medium [160].

Some cell wall components of probiotic bacteria exhibit AO properties. Exopolysaccharides (EPSs) are a group of carbohydrate polymers that play important roles in biofilm formation and cell adhesion. EPSs that are typically released by probiotic bacteria potentially play a role in oxidative stress reduction [161-163]. The AO activity of EPSs of lactobacilli has been repeatedly shown. EPSs are synthesized by a wide range of lactobacilli, including L. plantarum, L. helveticus, L. gasseri, and L. sakei [164]. In vitro testing of the AO activity of EPS-1 of L. helveticus KLDS1.8701 demonstrated strong scavenging properties on 2,2-diphenyl-1-picrylhydrazyl radicals, superoxide radicals, and hydroxyl radicals, as well as chelation of ferrous ions. Mice injected with D-gal EPS-1 showed significantly attenuated indicators of excessive oxidation, such as decreased organic index, liver injury, and liver oxidative stress. EPS-1 supplementation shifted the gut microbiota composition to that of the control group [165]. The synthesis of EPS is encoded by many genes, which are mainly organized in operons [166,167].

Many organisms can fully compensate for the loss of enzymatic AO defenses by accumulating metabolites and $\mathrm{Mn}^{2+}$. There is mounting evidence that $\mathrm{Mn}-\mathrm{Pi}$ (orthophosphate) complexes act as potent scavengers of superoxide in all three branches of life. Moreover, it is evident that $\mathrm{Mn}^{2+}$ complexes with carbonates, peptides, nucleosides, and organic acids can also form catalytic Mn-AOs, pointing to diverse metabolic routes to resistance to OS. $\mathrm{Mn}$ can serve as an $\mathrm{O}_{2}$ scavenger within SOD-deficient lactobacilli cells, such as L. plantarum. It has been demonstrated that the activity of MnSOD is dependent on the intracellular concentration of $\mathrm{Mn}^{2+}$ [168]. Both the fermented supernatant and the cell homogenate of L. plantarum MA2 strain lacking SOD exhibited superoxide dismutase activity [169]. In L. plantarum, which lacks AO enzymes, Mn-antioxidants can serve as additional protection when enzymatic antioxidants are insufficient [170]. In L. plantarum, which lacks AO enzymes, Mn-antioxidants can serve as additional protection when enzymatic antioxidants are insufficient [170]. Manganese transporters encoded by $m n t \mathrm{H} 1-m n t \mathrm{H} 2$, and ABC-type manganese transporters encoded by the $m t s$ CBA cluster of $L$. casei Shirota, are involved in the accumulation of intracellular manganese, and are necessary for aerobic growth of the strain [171]. Manganese can protect bifidobacteria from OS by acting as a scavenger of both $\mathrm{O}_{2}$ and $\mathrm{H}_{2} \mathrm{O}_{2}$, in addition to several crucial roles in biological systems. The expression of the zntA1 (BBMN68_1149) gene, encoding a homologue of the P-type ATPase that may be involved in taking up $\mathrm{Mn}^{2+}$, was upregulated 2.01-fold following exposure to oxygen in B. longum BBMN68 for 60 min [105]. In addition, B. longum BBMN68 grew faster in MRS broth supplemented with Mn2+ upon exposure to $3 \%$ oxygen [105].

\subsection{Effects on Cellular Receptors and Regulation of Internal Signal Transduction Systems of Eukaryotic Cells}

Probiotic bacteria can stimulate the activity of host AO enzymes. Increased activity of SOD, catalase, GSH S-transferase, GSH, and GSH peroxidase following Lactobacillus supplementation have been observed not only in blood serum, but also in diverse tissuesincluding the liver-in various animals [172].

In recent years, both in vivo and in vitro studies have reported that probiotic bacteria can protect against OS through regulation of the Nrf2-Keap1-ARE pathway [30] (Figure 2). 
A number of signaling pathways associated with the $\mathrm{AO}$ mechanisms of probiotic bacteria in host cells also include silent information regulator 1 (SIRT1), mitogen-activated protein kinase (MAPK), and protein kinase C (PKC).

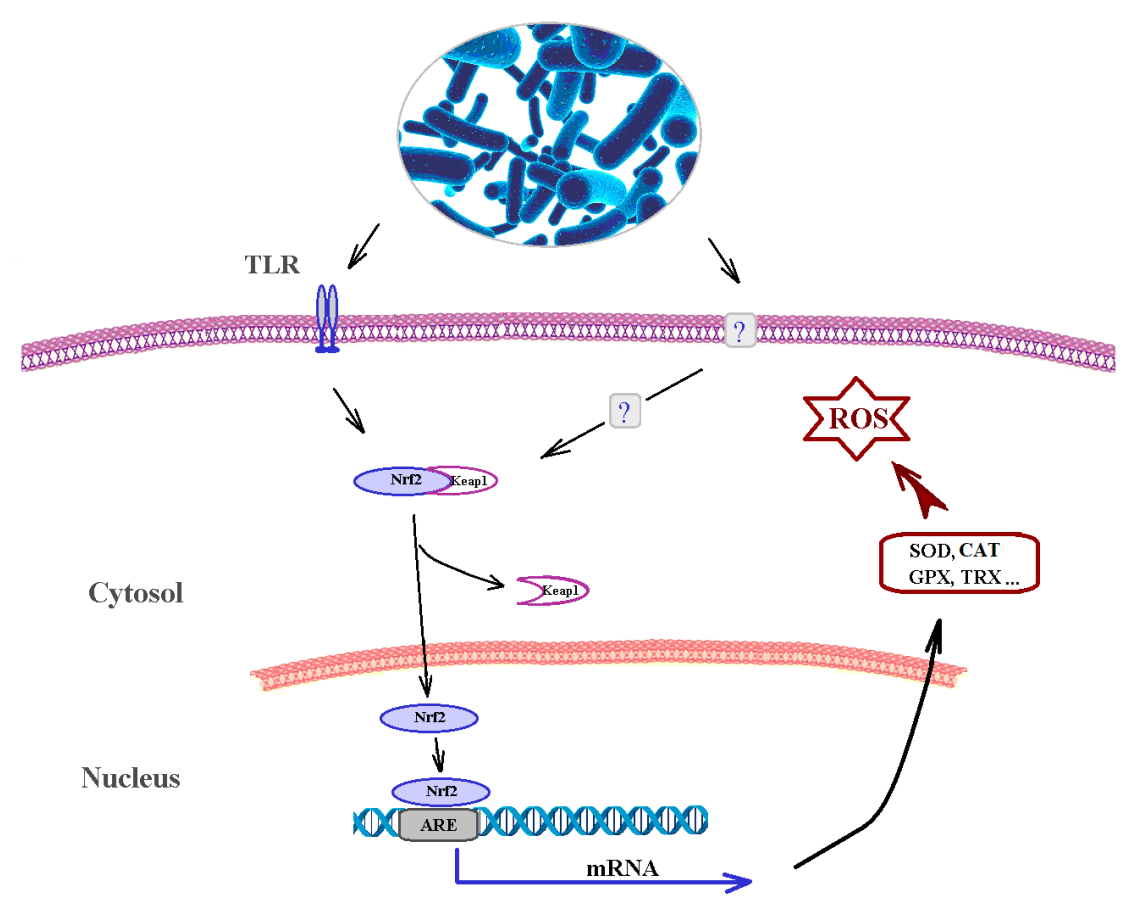

Figure 2. Effects of lactobacilli and bifidobacteria on cellular receptors and regulation of internal signal transduction systems of eukaryotic cells. ?: identified but undefined receptors and signaling molecules.

Nrf2-Keap1-ARE is an AO system that enables signal transmission from the outside into the cell and the nucleus. Under normal conditions, Keap1 is associated with Nrf2. Following ROS infiltration into the cell, the bond between Keap1 and Nrf2 is cleaved, and Nrf2 is transported into the nucleus, where it binds to ARE (antioxidant responsive element) sequences, activating the transcription of ARE-driven genes encoding AO enzymes [173]. Animals treated with L. plantarum CAI6 or L. plantarum SC4 demonstrated increased levels of Nrf2 in the liver and kidneys compared to the control group [29]. Saeedi et al. showed that oral administration of L. rhamnosus GG induced Nrf2 in the livers of normal mice, and this activation was sufficient to protect against two different models of acute oxidative liver damage (acetaminophen overdose and acute ethanol toxicity) [174].

SIRTs are an evolutionarily conserved family of NAD-dependent protein deacetylases that play an important $\mathrm{AO}$ role in mammalian and bacterial cells through the regulation of key genes and molecules that are an integral part of redox homeostasis [175]. Functional studies of probiotic SIRs are rare. However, there is a hypothesis that SIR2 plays the same $\mathrm{AO}$ role in probiotics as in eukaryotes. Guo et al. demonstrated that genes similar to SIR2 exist in B. longum and L. acidophilus, and are likely to increase aerotolerance by increasing AO enzyme activity [176]; these authors demonstrated that $B$. longum SIR2 upregulated the expression and activity of $\mathrm{AO}$ enzymes by deacetylating of the transcription protein $\operatorname{SigH}\left(\sigma^{\mathrm{H}}\right)$. Moreover, B. longum SIR2 can deacetylate the transcription factor FOXO3a in HEK293T cells, which mediates the gene expression of AO compounds. In vitro experiments on human T cells showed that SIR2 of B. longum can activate MnSOD/SOD2 and CAT, reducing the levels of ROS in human cells [176]. The administration of the probiotic formulation LAB51 - consisting of bifidobacteria, lactobacilli, and Streptococcus thermophilus- to a mouse clearly reduced OS, which was mediated by increased activity and expression of SIRT1 [110]. The sir2 gene encoding NAD-dependent protein deacetylase of the SIR2 family was found in the genome of B. longum LTBL16 [176,177]. SIR2 proteins can improve foxo-dependent transcription of antioxidants. B. longum with the sir2 gene can eliminate 
free radicals from human cells, thus slowing down aging and reducing the incidence of cancer, heart disease, and other diseases [177]. Knockout of sir2 from L. acidophilus decreases the $\mathrm{AO}$ activities of the deficient strain, while the reintroduction of LA-sir2 restores the strain's AO activities [176].

Mitogen-activated protein kinases (MAPKs) are involved in many signaling pathways, including those associated with OS. MAPKs include four subfamilies, the best characterized of which are the extracellular regulated protein kinases (ERKs), c-jun N-terminal kinases (JNKs), and p38-MAPK; these can be activated by a variety of stimuli [178]. Tao et al. suggested that pretreatment of cells with L. rhamnosus GG-CM alone activated all three MAPKs that they studied [179]. Following administration of L. gasseri SBT2055 (LG2055) to C. elegans, SKN-1 (an Nrf ortholog) was activated, which induced the transcription of AO genes via p38, the MAPK pathway [180]. Another study discovered that LG2055 activated JNK, while inhibiting JNK led to the suppression of Nrf-2 ARE signaling activation and the protection against OS in mammalian cells [181].

PKC is a family of protein kinases that phosphorylate hydroxyl groups of serine and threonine residues in proteins. PKC is a target of redox modification for its unique structural features [182]. Zhou et al. showed that administration of L. plantarum improved intestinal barrier function and OS in a rat model of obstructive jaundice by strengthening the expression and activity of the PKC pathway [183]. Epithelial barrier disruption induced by $\mathrm{H}_{2} \mathrm{O}_{2}$ can be improved using the soluble proteins $\mathrm{p} 40$ and $\mathrm{p} 75$, produced by L. rhamnosus GG through a PKC- and MAPK-dependent mechanism [184].

NF- $\mathrm{KB}$ is the eukaryotic transcription factor that responds to OS. ROS can activate NF- $\mathrm{KB}$ entailing the expression of inflammatory cytokines. The probiotic formulation VSL\#3-containing lactobacilli, bifidobacteria, and streptococci-is able to inhibit NF- $\mathrm{kB}$ and induce heat shock proteins in the epithelial cells of the colon [185].

The interaction of microbial products with Toll-like (TLR) receptors promotes the release of signaling molecules that lead to the activation of the Nrf2-Keap signaling pathway. Dissociation of the Nrf2-Keap complex can occur under the influence of various factors: phosphorylation of $\mathrm{Nrf2}$ by various protein kinases (PKC: protein kinase C; JNK: a group of stress activated kinases and other factors; SOD: superoxide dismutase; CAT: catalase; GSH: reduced glutathione; GPX: glutathione peroxidase; TRX: thioredoxin; NRF2: nuclear factor erythroid 2-related factor 2; Keap1: Kelch-like ECH-associated protein 1,arepressor protein associated with Nrf2; ARE: antioxidant-responsive element (ARE-genes).

\subsection{Impact on the Permeability of the Intestinal Barrier}

The main function of the intestinal barrier is to protect internal organs from harmful agents. An increase in intestinal permeability leads to the infiltration of endotoxins and other microbial metabolites into the bloodstream, and translocation of microorganisms that, via stimulation of TLR, initiate cellular immune responses, activate macrophages, and provoke inflammation and OS [186]. A dysfunctional barrier, as observed in several diseases, is often the cause of an increase in OS, eventually leading to dysbacteriosis [187]. One of the major functions of probiotic bacteria is metabolism of dietary components, which leads to the generation of active metabolites that regulate barrier function [188].

Conjugated fatty acids and indole derivatives-both metabolites of intestinal lactobacilli and bifidobacteria-are involved in the regulation of intestinal permeability [188]. Conjugated fatty acids, such as conjugated linoleic acid (CLA), are known to influence gut barrier function. Treatment with the trans-10 CLA isomer caused a redistribution of ZO-1 and OCLN and increased paracellular permeability in Caco-2 colon epithelial cells [189]. A gene encoding for linoleic acid isomerase was found in the genomes of different species of bifidobacteria [190,191].

Small-molecule metabolites, produced by gut microbes derived from dietary tryptophan (indole-3-ethanol, indole-3-pyruvate, and indole-3-aldehyde), improve intestinal barrier integrity and protect against inflammation. 
Metabolites of lactobacilli and bifidobacteria-such as secreted proteins, bacteriocins, and organic acids-increase mucus secretion by goblet cells' production of antimicrobial peptides, as well as expression of tight junction proteins [192]. Extracellular proteins secreted by L. plantarum BMCM12 effectively keep pathogens from adhering to epithelial cells. The soluble protein HM0539, derived from L. rhamnosus GG, mediates tight junction expression and mucus secretion [193]. B. infantis secretes proteins that positively regulate occludin and ZO-1 proteins, and increase TER, thus reducing colonic permeability [194]. Bacterial-derived butyrate increased the expression of tight junction proteins in vivo [195], and stimulated goblet cells to secrete mucin-especially MUC2 [196]. Bifidobacteria produce acetate and lactate that can be converted into butyrate by other colonic bacteria via cross-feeding [41]. The surface components of probiotic cells-such as membrane proteins, capsule polysaccharides, flagella, and pili-form molecular patterns that specifically bind to pattern recognition receptors and regulate signaling pathways, increasing the levels of cytokines countering inflammation and enhancing the function of the gut epithelium. Microintegral membrane proteins of $L$. plantarum can restore injury caused to tight junctions by increasing the expression of JAM-1, occludins, and claudin-1 [197]. Tad pili of bifidobacteria can stimulate neonatal mucosal growth and intestinal maturation [198].

Table 2. A gene catalog comprising the key bacterial enzymes relevant to antioxidation.

\begin{tabular}{|c|c|c|c|c|}
\hline Enzyme Name & Function & Gene & Strain & References \\
\hline Superoxide dismutase & Superoxide anion scavenging. & LSEI_RS08890 & L. paracasei ATCC 334 & {$[168]$} \\
\hline $\begin{array}{c}\text { Catalase } \\
\text { manganese-dependent }\end{array}$ & $\begin{array}{l}\text { Catalyzes the decomposition } \\
\text { of hydrogen peroxide to water } \\
\text { and oxygen. }\end{array}$ & C1940_16840 & $\begin{array}{l}\text { L. plantarum LB1-2, } \\
\text { Plasmid pLB1-2A }\end{array}$ & [46] \\
\hline $\begin{array}{c}\text { Catalase } \\
\text { heme-dependent }\end{array}$ & $\begin{array}{l}\text { Catalyzes the decomposition } \\
\text { of hydrogen peroxide to water } \\
\text { and oxygen. }\end{array}$ & $\begin{array}{c}\text { kat } \\
\text { Lpsk_RS08010 }\end{array}$ & L. plantarum 90sk & [199] \\
\hline Ferredoxin & Iron chelation activity. & BL1563 & B. longum NCC2705 & {$[83,84]$} \\
\hline $\begin{array}{c}\text { Peroxidase } \\
\text { (thiol peroxidase) }\end{array}$ & $\begin{array}{l}\text { Shows substrate specificity } \\
\text { toward alkyl hydroperoxides } \\
\text { over hydrogen peroxide. }\end{array}$ & $\begin{array}{c}t p x \\
\text { Lb15f_RS10100 }\end{array}$ & L. brevis $15 \mathrm{f}$ & [95] \\
\hline $\begin{array}{c}\text { Peroxidase } \\
\text { (DyP-type haem peroxidase) }\end{array}$ & $\begin{array}{c}\text { Wide substrate specificity, } \\
\text { degrades the typical } \\
\text { peroxidase substrates. }\end{array}$ & BWL06_08750 & L. plantarum KLDS1.0391 & [199] \\
\hline $\begin{array}{l}\text { Glutamate-cysteine ligase } \\
\text { ( } \gamma \text {-glutamylcysteine } \\
\text { synthetase })\end{array}$ & $\begin{array}{l}\text { Glutathione synthesis, } \\
\text { first stage. }\end{array}$ & $\begin{array}{c}g h s A \\
\text { AAX72_RS0316 } \\
\text { HMPREF9003_RS10030 }\end{array}$ & $\begin{array}{c}\text { L. brevis } 47 \mathrm{f} \\
\text { B. dentium JCVIHMP022 }\end{array}$ & $\begin{array}{l}{[119,199],} \\
\text { BioCyc }\end{array}$ \\
\hline $\begin{array}{c}\text { gamma-glutamate-cysteine } \\
\text { ligase/glutathione } \\
\text { synthetase }\end{array}$ & $\begin{array}{l}\text { Glutathione synthesis, } \\
\text { both stages. }\end{array}$ & $\begin{array}{c}g h s F(\mathrm{AB}) \\
\text { BWL06_02245, }\end{array}$ & L. plantarum KLDS1.0391 & {$[119,120]$} \\
\hline Glutathione peroxidase & $\begin{array}{l}\text { Reduces glutathione to } \\
\text { glutathione disulfide; } \\
\text { reduces lipid hydroperoxides } \\
\text { to alcohols. }\end{array}$ & $\begin{array}{c}\text { gpo, } \\
\text { BWL06_06975 }\end{array}$ & L. plantarum KLDS1.0391 & {$[122,199]$} \\
\hline Glutathione S-transferase & $\begin{array}{l}\text { Catalyzes the conjugation of } \\
\text { the reduced form of } \\
\text { glutathione (GSH) to } \\
\text { xenobiotic substrates. }\end{array}$ & 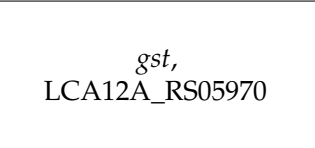 & L. casei $12 \mathrm{~A}$ & {$[122]$} \\
\hline Glutathione reductase & $\begin{array}{l}\text { Catalyzes the reduction of the } \\
\text { oxidized form of glutathione } \\
\text { (GSSG) to the reduced form. }\end{array}$ & $\begin{array}{l}\text { gshR/gor, } \\
\text { BWL06_06300, } \\
\text { BWL06_09445 }\end{array}$ & L. plantarum KLDS1.0391 & {$[126,199]$} \\
\hline $\begin{array}{l}\text { Thiol reductant } \mathrm{ABC} \\
\text { exporter subunit } \mathrm{CydC}\end{array}$ & Glutathione import. & $\begin{array}{c}c y d C, \\
\text { C0965_RS00870 }\end{array}$ & L. fermentum U-21 & {$[121]$} \\
\hline
\end{tabular}


Table 2. Cont.

\begin{tabular}{|c|c|c|c|c|}
\hline Enzyme Name & Function & Gene & Strain & References \\
\hline $\begin{array}{l}\text { Thiol reductant } \mathrm{ABC} \\
\text { exporter subunit } \mathrm{CydD}\end{array}$ & Glutathione import. & $\begin{array}{c}\text { cydD, } \\
\text { C0965_RS00865 }\end{array}$ & L. fermentum U-21 & [121] \\
\hline Glutaredoxin & $\begin{array}{l}\text { Reduce dehydroascorbate, } \\
\text { peroxiredoxins, and } \\
\text { methionine sulfoxide } \\
\text { reductase. Reduced } \\
\text { non-enzymatically } \\
\text { by glutathione. }\end{array}$ & $\begin{array}{c}g r x A \\
\text { ACT00_RS12315 } \\
\text { grx1, grxC2 } \\
\text { BBMN68_1397 }\end{array}$ & $\begin{array}{l}\text { L. rhamnosus } 313 \\
\text { B. longum BBMN68 }\end{array}$ & {$[83,105,126]$} \\
\hline $\begin{array}{l}\text { Glutaredoxin-like } \\
\text { NrdH protein }\end{array}$ & $\begin{array}{l}\text { Characterized by a } \\
\text { glutaredoxin-like amino acid } \\
\text { sequence and thioredoxin-like } \\
\text { activity profile. Reduced by } \\
\text { thioredoxin reductase. }\end{array}$ & $\begin{array}{c}n r d \\
\text { HC0965_RS00895 BL0668 }\end{array}$ & $\begin{array}{l}\text { L. fermentum U-21 } \\
\text { B. longum NCC2705 }\end{array}$ & [121] \\
\hline $\begin{array}{l}\text { Peroxiredoxin } \\
\text { (alkyl hydroperoxide } \\
\text { reductase subunit C) }\end{array}$ & $\begin{array}{c}\text { Reduces } \mathrm{H}_{2} \mathrm{O}_{2} \text {, organic } \\
\text { peroxides, and peroxynitrite. }\end{array}$ & $\begin{array}{c}\text { tpx }(\operatorname{ahpC}) \\
\text { C0965_RS09890, } \\
\text { ahpC, } \\
\text { BL0615 }\end{array}$ & $\begin{array}{l}\text { L. fermentum U-21 } \\
\text { B. longum NCC2705 }\end{array}$ & {$[105,106,108]$} \\
\hline $\begin{array}{l}\text { Alkyl hydroperoxide } \\
\text { reductase, subunits F }\end{array}$ & $\begin{array}{l}\text { Catalyzes the } \\
\text { NADH-dependent reduction } \\
\text { of the peroxiredoxin AhpC. }\end{array}$ & $\begin{array}{c}a h p F, \\
\text { LM010_05765 }\end{array}$ & L. manihotivorans LM010 & [200] \\
\hline $\begin{array}{l}\text { Peroxideroxin } \\
\text { OsmC family }\end{array}$ & $\begin{array}{l}\text { Peroxidase activity with a } \\
\text { strong preference for } \\
\text { organic hydroperoxides. }\end{array}$ & $\begin{array}{l}\text { C0965_RS08900 } \\
\text { BLI010_09070 }\end{array}$ & $\begin{array}{l}\text { L. fermentum U-21 } \\
\text { B. infantis JCM } 7010\end{array}$ & [200] \\
\hline Peroxiredoxin Q/BCP & $\begin{array}{l}\text { Protein reduces and detoxifies } \\
\text { hydroperoxides, shows } \\
\text { substrate selectivity toward } \\
\text { fatty acid hydroperoxides. }\end{array}$ & $\begin{array}{l}\text { LTBL16_000976 } \\
\text { BL0615 }\end{array}$ & $\begin{array}{l}\text { B. longum LTBL16 } \\
\text { B. longum NCC2705 }\end{array}$ & {$[83,104,177]$} \\
\hline Thioredoxin & $\begin{array}{l}\text { Reduction of disulfide bonds } \\
\text { of other proteins by cysteine } \\
\text { thiol-disulfide exchange. }\end{array}$ & $\begin{array}{c}\operatorname{trxA} A, B, \\
\text { BWL06_01960, } \\
\text { BWL06_03620, } \\
\text { BWL06_06900, } \\
\text { BWL06_08715, } \\
\text { BBMN68_991, } \\
\text { BLD_0988 }\end{array}$ & $\begin{array}{l}\text { L. plantarum KLDS1.0391 } \\
\text { B. longum DJO10A }\end{array}$ & {$[83,103,105,112,199]$} \\
\hline Thioredoxin reductase & $\begin{array}{l}\text { Reduction of oxidized } \\
\text { thioredoxins and } \\
\text { glutaredoxin-like } \\
\text { NrdH protein. }\end{array}$ & $\begin{array}{c}\operatorname{trxC}, \\
\text { BWL06_10585, } \\
\text { trxB, } \\
\text { BBMN68_RS07015 } \\
\text { EH079_RS10430 } \\
\text { BL0649 }\end{array}$ & $\begin{array}{l}\text { L. plantarum KLDS1.0391 } \\
\text { B. longum BBMN68 } \\
\text { B. longum LTBL16 } \\
\text { B. longum NCC2705 }\end{array}$ & [103-105,108,177,199] \\
\hline NAD(P)H oxidase & $\begin{array}{l}\text { Source of cellular reactive } \\
\text { oxygen species, transfers } \\
\text { electrons from NADPH to } \\
\text { oxygen molecule. }\end{array}$ & $\begin{array}{c}\text { nox, } \\
\text { BWL06_00410 } \\
\text { BWL06_08660 } \\
\text { LTBL16_001911 }\end{array}$ & $\begin{array}{l}\text { L. plantarum KLDS1.0391 } \\
\text { B. longum LTBL16 }\end{array}$ & {$[95,108,177,199]$} \\
\hline NAD(P)H peroxidase. & Reduces $\mathrm{H}_{2} \mathrm{O}_{2}$ to water. & $\begin{array}{l}\text { BWL06_10580, } \\
\text { BWL06_10615, } \\
\text { BWL06_12965 }\end{array}$ & L. plantarum KLDS1.0391 & [199] \\
\hline $\begin{array}{l}\text { NADH flavin } \\
\text { oxidoreductase }\end{array}$ & $\begin{array}{l}\text { Enzyme reduces free flavins } \\
\text { by NADH. Is inducible by the } \\
\text { hydrogen peroxide. }\end{array}$ & $\begin{array}{l}\text { BWL06_01550 } \\
\text { BWL06_07320 }\end{array}$ & L. plantarum KLDS1.0391 & [199] \\
\hline Pyruvate oxidase & $\begin{array}{l}\text { Catalyzes the oxidative } \\
\text { decarboxylation of pyruvate in } \\
\text { the presence of phosphate and } \\
\text { oxygen, yielding acetyl } \\
\text { phosphate, carbon dioxide, } \\
\text { and hydrogen peroxide. }\end{array}$ & $\begin{array}{l}\text { BWL06_03605 } \\
\text { BWL06_08165 } \\
\text { BWL06_10985 } \\
\text { BWL06_10995 }\end{array}$ & L. plantarum KLDS1.0391 & [199] \\
\hline
\end{tabular}


Table 2. Cont.

\begin{tabular}{|c|c|c|c|c|}
\hline Enzyme Name & Function & Gene & Strain & References \\
\hline $\begin{array}{l}\text { Dihydroorotate } \\
\text { dehydrogenase }\end{array}$ & $\begin{array}{l}\text { Generates } \mathrm{H}_{2} \mathrm{O}_{2} \text {-forming } \\
\text { NADH oxidase activity and } \\
\text { indirect production of } \mathrm{H}_{2} \mathrm{O}_{2} \text {. }\end{array}$ & $\begin{array}{c}\text { BWL06_03855 } \\
\text { BWL06_09870 } \\
\text { pyrK } \\
\text { CNCMI_0917 } \\
\text { pyrD } \\
\text { CNCMI_0378 }\end{array}$ & $\begin{array}{l}\text { L. plantarum KLDS1.0391 } \\
\text { B.bifidum CNCMI-4319 }\end{array}$ & {$[114,199]$} \\
\hline $\begin{array}{l}\text { Oxygen-dependent } \\
\text { coproporphyrinogen } \\
\text { III oxidase }\end{array}$ & $\begin{array}{c}\text { Involved in detoxifying } \\
\text { molecular oxygen } \\
\text { and/or } \mathrm{H}_{2} \mathrm{O}_{2} \text {. }\end{array}$ & Balat_0893 & B. lactis DSM 10140 & {$[100]$} \\
\hline $\begin{array}{c}\text { Possible } \\
\text { Class I pyridine } \\
\text { nucleotide-disulfide } \\
\text { oxidoreductase (PNDR) }\end{array}$ & $\begin{array}{l}\text { Enzyme is involved in the } \\
\text { cellular oxidative } \\
\text { stress response. }\end{array}$ & $\begin{array}{c}\text { BL1626 } \\
\text { Lp19_3298 }\end{array}$ & $\begin{array}{l}\text { B. longum NCC } 2705 \\
\text { L. plantarum } 19.1\end{array}$ & {$[105,115]$} \\
\hline P-type ATPase & $\begin{array}{l}\text { Transport of manganese to the } \\
\text { bacterial cell. }\end{array}$ & $\begin{array}{c}\text { mntP } \\
\text { BWL06_09205 } \\
\text { zntA1 BBMN68_1149 }\end{array}$ & $\begin{array}{l}\text { L. plantarum KLDS1.0391 } \\
\text { B. longum BBMN68 }\end{array}$ & {$[105,199]$} \\
\hline $\begin{array}{l}\text { Manganese ABC transporter } \\
\text { ATP-binding protein }\end{array}$ & $\begin{array}{l}\text { Transport of manganese to the } \\
\text { bacterial cell. }\end{array}$ & BWL06_12065 & L. plantarum KLDS1.0391 & [199] \\
\hline ABC transporter & $\begin{array}{l}\text { Transport of manganese to the } \\
\text { bacterial cell. }\end{array}$ & BWL06_12070 & L. plantarum KLDS1.0391 & [199] \\
\hline $\begin{array}{l}\text { Metal ABC transporter } \\
\text { substrate-binding protein }\end{array}$ & $\begin{array}{l}\text { Transport of manganese to the } \\
\text { bacterial cell. }\end{array}$ & BWL06_12075 & L. plantarum KLDS1.0391 & [199] \\
\hline $\begin{array}{c}\text { Ferritin; ferroxidase; } \\
\text { DNA starvation/stationary } \\
\text { phase protection protein }\end{array}$ & $\begin{array}{l}\text { Enzymes catalyzes the } \\
\text { oxidation ofFe } 2+\text { ions by } \\
\text { hydrogen peroxide, which } \\
\text { prevents hydroxyl radical } \\
\text { production by the } \\
\text { Fenton reaction. }\end{array}$ & $\begin{array}{c}d p s, \\
\text { LBP_RS12440 } \\
\text { A1F92_RS15895 } \\
\text { BL0618 }\end{array}$ & $\begin{array}{l}\text { L. plantarum } \mathrm{P}-8 \\
\text { L. plantarum CAUH2 } \\
\text { plasmid pCAUH203 } \\
\text { B. longum NCC2705 }\end{array}$ & {$[108,113]$} \\
\hline DsbA family oxidoreductase & $\begin{array}{l}\text { Catalyzes intrachain disulfide } \\
\text { bond formation as peptides } \\
\text { emerge into the } \\
\text { cell's periplasm. }\end{array}$ & $\begin{array}{c}d s b A, \\
\text { LBHH_RS12125, } \\
\text { A1F92_RS15940 } \\
\text { MCC00353_12020 }\end{array}$ & $\begin{array}{l}\text { L. helveticus } \mathrm{H} 10, \\
\text { L. plantarum CAUH2 } \\
\text { pCAUH203, } \\
\text { B. longum MCC00353 }\end{array}$ & $\begin{array}{c}{[113]} \\
\text { BioCyc }\end{array}$ \\
\hline $\begin{array}{l}\text { Hydrogen peroxide } \\
\text { resistance protein }\end{array}$ & $\begin{array}{l}\text { Upregulated by both oxygen } \\
\text { and hydrogen peroxide stress. }\end{array}$ & hprA1 & L. casei strain Shirota. & {$[112]$} \\
\hline $\begin{array}{l}\text { Transcriptional regulator. } \\
\text { Copper transporting ATPase }\end{array}$ & $\begin{array}{l}\text { Metabolism/chelation of } \\
\text { copper ions. }\end{array}$ & $\begin{array}{c}\text { copR, } \\
\text { JDM1_2697, } \\
\text { copB, } \\
\text { JDM1_2696 }\end{array}$ & L. plantarum JDM1 & [86] \\
\hline Ribonucleotide reductase & $\begin{array}{c}\text { DNA oxidative } \\
\text { damage-protective protein. }\end{array}$ & $\begin{array}{c}\text { nrdA, } \\
\text { BL1752 } \\
\text { LBP_cg2187 }\end{array}$ & $\begin{array}{l}\text { B. longum } \mathrm{NCC} 2705 \\
\text { L. plantarum } \mathrm{P}-8\end{array}$ & {$[105,109]$} \\
\hline $\begin{array}{l}\text { Nucleotide triphosphate } \\
\text { pyrophosphohydrolases }\end{array}$ & $\begin{array}{c}\text { DNA oxidative } \\
\text { damage-protective proteins. }\end{array}$ & mut $\mathrm{T} 1$ & B. longum BBMN68 & {$[105]$} \\
\hline $\begin{array}{l}\text { Phytoene synthase } \\
\text { Phytoene desaturase }\end{array}$ & Biosynthesis of carotenoids. & $\begin{array}{c}\text { crtM, GMA16_RS13840, } \\
\text { crtN GMA16_RS13835 }\end{array}$ & L. plantarum КССР11226 & {$[151]$} \\
\hline Histidine decarboxylase & Synthesis of histamine. & LAR_RS09695 & L. reuteri JCM 1112 & [152] \\
\hline $\begin{array}{l}\text { NAD-dependent protein } \\
\text { deacetylase of SIR2 family }\end{array}$ & $\begin{array}{l}\text { Involved in the response to } \\
\text { oxidative stress. NAD + } \\
\text {-dependent deacetylation of } \\
\sigma \mathrm{H} \text { and transcription factor } \\
\text { FOXO3a. Improve } \\
\text { foxo-dependent transcription } \\
\text { of antioxidant enzymes and } \\
\text { reduce ROS levels in cells. }\end{array}$ & $\begin{array}{c}\text { sir2, } \\
\text { LP_RS01895, } \\
\text { LTBL16_002010 }\end{array}$ & $\begin{array}{l}\text { L. plantarum WSFS1 } \\
\text { B. longum LTBL16 }\end{array}$ & {$[82,176]$} \\
\hline Linoleic acid isomerase & $\begin{array}{l}\text { Partcipates in linoleic acid } \\
\text { metabolism. Conjugated } \\
\text { linoleic acid metabolites } \\
\text { exhibit the ability to protect } \\
\text { cells from oxidative effects. }\end{array}$ & $\begin{array}{c}l a i \\
\text { CNCMI4319_0491 } \\
\text { SN35N_1476 }\end{array}$ & $\begin{array}{l}\text { B. bifidum CNCM I-4319 } \\
\text { L. plantarum SN35N }\end{array}$ & {$[190]$} \\
\hline
\end{tabular}


Table 2. Cont.

\begin{tabular}{|c|c|c|c|c|}
\hline Enzyme Name & Function & Gene & Strain & References \\
\hline $\begin{array}{l}\text { Cyclopropane-fatty-acyl- } \\
\text { phospholipid synthase }\end{array}$ & $\begin{array}{l}\text { Catalyzes cyclopropane fatty } \\
\text { acid (cell-surface } \\
\text { component) biosynthesis. }\end{array}$ & $\begin{array}{l}\text { BBMN68_1705 } \\
\text { EC76_GL001195 } \\
\text { EC76_GL002960 }\end{array}$ & $\begin{array}{l}\text { B. longum BBMN68 } \\
\text { L. plantarum } \\
\text { ATCC } 14917\end{array}$ & {$[105]$} \\
\hline Feruloyl esterase & $\begin{array}{l}\text { Hydrolyzes and releases } \\
\text { ferulic acid from its } \\
\text { bound state. }\end{array}$ & LA20079_RS01515 & $\begin{array}{l}\text { L. acidophilus } \\
\text { DSM } 20079\end{array}$ & {$[145]$} \\
\hline $\begin{array}{c}\text { Riboflavin } \\
\text { biosynthesis operon }\end{array}$ & Riboflavin biosynthesis. & $\begin{array}{l}\text { ribA, } B, H, G, \\
\text { Lpsk_RS01975, } \\
\text { Lpsk_RS01960, } \\
\text { Lpsk_RS01970, } \\
\text { Lpsk_RS01965 }\end{array}$ & L. plantarum 90sk & {$[158]$} \\
\hline Cobalamin biosynthesis & Cobalamin biosynthesis. & At least 30 genes & L. reuteri JCM 112(T) & {$[155]$} \\
\hline $\begin{array}{l}\text { Hydroxycinnamic } \\
\text { acid esterase }\end{array}$ & $\begin{array}{c}\text { Release of hydroxycinnamates } \\
\text { from plant-based } \\
\text { dietary sources. }\end{array}$ & caeA & B. longum & {$[141]$} \\
\hline $\begin{array}{l}\text { S-adenosylhomocysteinase, } \\
\text { S-ribosylhomocysteinase }\end{array}$ & $\begin{array}{l}\text { Synthesizes cysteine from } \\
\text { methionine using } \\
\text { homocysteine as } \\
\text { an intermediate. }\end{array}$ & $\begin{array}{c}\text { ahcY,luxS } \\
\text { BLIJ_2075 } \\
\text { FC12_GL001705 }\end{array}$ & $\begin{array}{l}\text { B. infantis ATCC } 15697 \\
\text { L. paracasei subsp. } \\
\text { tolerans DSM } 20258\end{array}$ & [131] \\
\hline $\begin{array}{l}\text { Subtilisin-like serine } \\
\text { protease, cell } \\
\text { envelope protease }\end{array}$ & $\begin{array}{l}\text { Catalyzes the cleavage of } \\
\text { peptide bonds. }\end{array}$ & $\begin{array}{l}\text { aprE, } \\
\text { cep }\end{array}$ & B. longum KACC91563 & {$[130]$} \\
\hline Tyramine dehydrogenase & $\begin{array}{l}\text { p-Hydroxyphenylacetate } \\
\text { production. }\end{array}$ & hpa & Bifidobacterium spp. & {$[134]$} \\
\hline Indolelactate dehydratase & Indoleacrylic acid production. & gene cluster (fldAIBC) & Bifidobacterium spp. & [132] \\
\hline Phenyllactate dehydratase & $\begin{array}{l}\text { Indolepropionic acid } \\
\text { production. }\end{array}$ & gene cluster (fldAIBC) & Bifidobacterium spp. & {$[132]$} \\
\hline $\begin{array}{l}\text { 4-Amino-4- } \\
\text { deoxychorismate lyase }\end{array}$ & Tetrahydrofolate production. & $\begin{array}{c}p a b C \\
\text { LOSG293_010660 }\end{array}$ & $\begin{array}{c}\text { B. adolescentis } \\
\text { ATCC15703, } \\
\text { B. pseudocatenulatum } \\
\text { Schleiferilactobacillus } \\
\text { oryzae JCM } 18671\end{array}$ & [148-151] \\
\hline $\begin{array}{l}\text { PLP synthase: } \\
\text { pyridoxal 5'-phosphate } \\
\text { synthase PdxS subunit, } \\
\text { pyridoxal } 5^{\prime} \text {-phosphate } \\
\text { synthase PdxT subunit }\end{array}$ & $\begin{array}{l}\text { Pyridoxal } \\
\text { phosphate production. }\end{array}$ & $\begin{array}{l}p d x S \\
p d x T\end{array}$ & $\begin{array}{l}\text { B. longum, } \\
\text { B. adolescentis }\end{array}$ & {$[147,150]$} \\
\hline $\begin{array}{l}\text { Cobaltochelatase, } \\
\text { adenosylcobyric acid } \\
\text { synthase }\end{array}$ & Adenosylcobalamin synthesis. & $\begin{array}{c}c o b Q \\
\text { LSA02_15070 }\end{array}$ & $\begin{array}{l}\text { B. animalis, } \\
\text { B. infantis, } \\
\text { B. longum, } \\
\text { L. sakei } \\
\text { NBRC } 5893\end{array}$ & {$[152,154]$} \\
\hline 9 and 10-Dehydroxylase & $\begin{array}{c}\text { Conversion of ellagic acid into } \\
\text { urolithin A. }\end{array}$ & & $\begin{array}{l}\text { B. pseudocatenulatum } \\
\text { INIA P815 }\end{array}$ & [149] \\
\hline
\end{tabular}

\section{Perspectives for the Applications of the Antioxidant Properties of Probiotic Lactobacilli and Bifidobacteria}

Inflammation and OS are common symptoms of chronic diseases: autoimmune, neurological, cardiac, and oncological. The development of chronic diseases is often accompanied by dysbiosis or dysfunction of the gut microbiome [201]. Probiotic bacteria of the families Lactobacillaceae and Bifidobacteriaceae are promising candidates for antioxidant drugs [202,203]. The development of drugs aimed at eliminating the gut microbiome inflammatory phenotype will be facilitated considerably if novel methodological and conceptual approaches are implemented in the search for unique strains of probiotic bacteria; these include comparative analysis of the genomes of lactobacilli and bifidobacteria, as well as metagenomes of the gut microbiome of healthy people and patients with chronic inflammatory diseases using omics technologies. The characterization of the gut microbiome 
in health and disease is more likely to become possible when biomarkers of a dysfunctional microbiome are better understood.

Today, research is underway to identify the genes accounting for the neuromodulatory and immunomodulatory properties of the gut microbiome. The neuromodulatory potential of the human gut microbiome has been studied since the emergence of the concept of the gut-brain axis. Potential biomarkers that account for the neuromodulatory potential of a gut microbiome have been identified $[38,204,205]$. The immunomodulatory potential of the human gut microbiome - and lactobacilli and bifidobacteria, in particular-is an interesting and novel topic for research [206].

However, research on the antioxidant properties of bacteria lacks systemization. This review systematically summarizes the accumulated knowledge on the antioxidant potential of bacteria, putting together a catalog of genes that encode proteins possessing antioxidant potential. The gene catalog could serve as a tool for the characterization of the antioxidant potential of the gut microbiome in health and disease.

The assessment of the antioxidant potential of the gut microbiome and probiotic bacteria is enabled by in silica analysis and development of algorithms. The first step is to identify the genes encoding products possessing antioxidant properties in the sequenced genomes of probiotic bacteria. The second step is to employ proteomic and metabolomic analyses to identify extracellular proteins and other compounds possessing antioxidant activity. The third step involves the assessment of the antioxidant properties of selected strains of probiotic bacteria in vitro, using cell lines and model organisms. This approach proved effective for the selection of strains such as L. brevis $47 \mathrm{f}$ and L. fermentum U-21, which possess outstanding antioxidant properties [61,71,72,206-209].

Correction of the gut microbiome of patients with chronic inflammatory diseases characterized by an imbalanced antioxidant system should be carried out using strains of probiotic bacteria with selected antioxidant properties. The gut microbiome of people resistant to OS can be mined for unique strains that can be used for the treatment of patients with chronic inflammatory diseases using a gut-microbiome-based approach.

The COVID-19 pandemic is a serious threat to public health, and not only because of the deaths numbering in the hundreds of thousands, but also because of the post-COVID-19 conditions that have complicated the lives of millions of people after they were infected. Complications of COVID-19 include autoimmune, cardiological, oncological, neurological, and chronic inflammatory conditions [210,211]. Public health systems around the world face a difficult task of rehabilitating hundreds of millions of people afflicted by COVID-19. The antioxidant properties of probiotics based on lactobacilli and bifidobacteria remain underestimated in this field [212]. For instance, the FN3 protein derived from B. longum GT15 has been shown to selectively bind to tumor necrosis factor alpha (TNF- $\alpha$ ) $[213,214]$. New perspectives emerge for the use of components of lactobacilli and bifidobacteria, rather than using them as live cultures. These are known today as postbiotics, which are defined as metabolites and cell components conferring health benefits [215,216]. Postbiotics are a promising field of research for future pharmaceuticals and functional foods possessing antioxidant properties for the treatment of depressive disorders [217]. The potential of postbiotics can be harnessed by packing them into nanostructures, allowing them to be delivered to organs affected by inflammation [218]. The use of extracellular vesicles of Gram-positive probiotic bacteria, which can freely enter the bloodstream as well as tissues and organs of the human body, are another exciting area of research $[219,220]$.

Metagenomics as a modern technique is extensively used not only to investigate differences in the microbiota composition in disease states compared to healthy individuals, but also to study functional genes of the gut microbiota. For this reason, it is desirable to use the metagenomic analysis of sequenced full-genomic bacterial DNA to study the AO potential of the gut microbiota. This approach can produce significant results when searching for target genes that are included in the reference gene catalog of the search tool. Table 2 provides a gene catalog comprising the key bacterial products relevant to the AO properties of probiotic lactobacilli and bifidobacteria. Orthologs of these genes 
could be identified in the available sequenced genomes of lactobacilli and bifidobacteriarepresentatives of the human intestinal microbiota-so as to search for them in the gut microbiota for the identification of the next potential AO biomarkers. An example of using a catalog of genes involved in the production of compounds related to ASD is presented in the study of Averina et al.; the use of such a methodological approach appeared to be effective for detecting significant changes in the metagenomic signature of the gut microbiota of children with ASD in comparison with neurotypical children [38]. VallesColomer et al. also used a catalog of bacterial genes encoding metabolites correlated with depressive disorders, in order to search for associations between the gut microbiota and depression [221]. Knowledge about AO bacterial markers can be used to diagnose OS, and also to provide indicators to monitor and guide individual therapy in the clinic.

\section{Conclusions}

Multiple in vivo and in vitro studies have demonstrated that lactobacilli and bifidobacteria, along with their components, possess outstanding antioxidant capacity that provides a certain degree of protection of both their own cells and those of their hosts against oxidative damage. An extensive body of research proves that probiotic bacteria are capable of imparting $\mathrm{AO}$ benefits to the human organism, preventing diseases associated with OS. Genomic, transcriptomic, and proteomic analyses of probiotic strains of lactobacilli and bifidobacteria allowed the detection of various intrinsic defense systems that protect cells from OS. The AO activity is more pronounced in lactobacilli, which is related to the fact that they are facultative anaerobes or microaerophiles. AO enzymes such as thioredoxin and GSH-glutaredoxin systems-and to a lesser extent superoxide dismutase and catalase-determine the AO properties of lactobacilli. The AO enzymes alkyl hydroperoxide reductase, thioredoxin reductase, and NADH oxidase are more common in bifidobacteria. The principal known mechanisms of AO activity employed by probiotic bacteria to reduce OS in the human organism include the regulation of complex signaling networks-mainly redox signaling of Nrf2-increase in AO enzyme levels, scavenging of ROS via different pathways, chelation of metal ions, improvement of gut permeability, and modulation of the intestinal microbiota. Cell wall components and metabolites of lactobacilli and bifidobacteria (e.g., EPS, tryptophan metabolites, histamine) contribute to an increase in the $\mathrm{AO}$ activity of host cells by acting on cellular receptors and regulating internal signal transduction. However, the $\mathrm{AO}$ action of probiotic bacteria in the human body has not been fully elucidated. In the near future, it is necessary to carry out comprehensive studies of the ways in which bacteria confer protection from OS to both their own cells and those of their hosts.

The studies of the antioxidant properties of bacteria, which allow for the identification of biomarkers of the antioxidant potential of lacto- and bifidobacteria strains, as well as the human gut microbiome, have not yet been systematized. In this review, the accumulated knowledge on the antioxidant potential of bacteria is systematized and a catalog of genes for antioxidant products of bacteria is presented, which can be used to characterize the antioxidant potential of the microbiome, including lactobacilli and bifidobacteria. The purpose of this review was to identify the AO biomarkers that characterize the potential of both individual strains and consortia of bacteria inhabiting the gut microbiota. These biomarkers can reflect the $\mathrm{AO}$ status of the host organism, as the analysis of metagenomic data from patients with different diseases was correlated with OS and altered gut microbiota. The creation of gene catalogs containing the antioxidative genes will allow for the full deciphering of metagenomic data. Mean while, defining the metagenomic AO signatures of lactobacilli and bifidobacteria in the norm is crucial for singling out the genes with diagnostic potential in the context of different diseases. The COVID-19 pandemic has mobilized the scientific community, business, and government agencies around the world to develop vaccines and drugs that can stop SARS-CoV-2 and reduce its socioeconomic consequences. Despite the progress in vaccine development, the number of new cases continues to rise. The data on the high risk of post-COVID-19 conditions after recovering 
from the disease are very alarming. Thus, intensive research is underway to reveal the link between inflammation, chronic diseases, and the gut microbiome.

It has been reported that following infection with SARS-CoV-2, the composition of the gut microbiome is altered, and characterized as dysbiotic. Overall, this is often accompanied by a decrease in the number of certain species of lactobacilli and bifidobacteria. Post-COVID-19 persistent dysbiosis can be a part of a multisystem inflammatory syndrome. It is well known that the gut microbiome is able to synthesize a complex of compounds with neuromodulatory, immunomodulatory, and antioxidant activity, which could characterize the gut microbiome.

Today, the gut microbiome is considered a valuable source for the development of pharmaceuticals, veterinary medicine, and functional foods. This is especially important in light of the urgent need for treating and rehabilitating a vast portion of the population in the post-COVID-19 era. Global advances in the study of the human microbiome, and the transition from classic probiotics such as dietary supplements to pharmabiotics, safe and with an established mechanism of action, open new horizons in personalized medicine.

Author Contributions: Conceptualization, O.V.A., V.N.D.; formal analysis and interpretation, O.V.A., E.U.P.; Writing—original draft preparation, O.V.A., E.U.P., M.V.M., V.N.D.; Writing-review and editing, O.V.A., E.U.P., V.N.D. All authors have read and agreed to the published version of the manuscript.

Funding: The study was granted by the Russian Foundation for Basic Research, project no. 20-5418006, and the Russian Science Foundation, project no. 20-14-00132.

Institutional Review Board Statement: Not applicable.

Informed Consent Statement: Not applicable.

Data Availability Statement: Not applicable.

Conflicts of Interest: The authors declare no conflict of interest.

\section{References}

1. Vona, R.; Pallotta, L.; Cappelletti, M.; Severi, C.; Matarrese, P. The Impact of Oxidative Stress in Human Pathology: Focus on Gastrointestinal Disorders. Antioxidants 2021, 10, 201. [CrossRef]

2. Sies, H.; Jones, D.P. Reactive oxygen species (ROS) as pleiotropic physiological signalling agents. Nat. Rev. Mol. Cell Biol. 2020, 21, 363-383. [CrossRef] [PubMed]

3. Watson, J. Oxidants, antioxidants and the current incurability of metastatic cancers. Open Biol. 2013, 3, 120144. [CrossRef]

4. Davalli, P.; Marverti, G.; Lauriola, A.; D'Arca, D. Targeting Oxidatively Induced DNA Damage Response in Cancer: Opportunities for Novel Cancer Therapies. Oxidative Med. Cell. Longev. 2018, 2018, 1-21. [CrossRef]

5. Zuo, L.; Prather, E.R.; Stetskiv, M.; Garrison, D.E.; Meade, J.R.; Peace, T.I.; Zhou, T. Inflammaging and oxidative stress in human diseases: From molecular mechanisms to novel treatments. Int. J. Mol. Sci. 2019, 20, 4472. [CrossRef] [PubMed]

6. Domej, W.; Oetll, K.; Renner, W. Oxidative stress and free radicals in COPD-Implications and relevance for treatment. Int. J. Chronic Obstr. Pulm. Dis. 2014, 9, 1207-1224. [CrossRef] [PubMed]

7. Rana, A.K.; Singh, D. Targeting glycogen synthase kinase-3 for oxidative stress and neuroinflammation: Opportunities, challenges and future directions for cerebral stroke management. Neuropharmacology 2018, 139, 124-136. [CrossRef] [PubMed]

8. Kalogeris, T.; Baines, C.P.; Krenz, M.; Korthuis, R.J. Ischemia/Reperfusion. Compr. Physiol. 2016, 7, 113-170.

9. Soares, R.O.S.; Losada, D.M.; Jordani, M.C.; Évora, P.; Castro, E.; Silva, O. Ischemia/Reperfusion Injury Revisited: An Overview of the Latest Pharmacological Strategies. Int. J. Mol. Sci. 2019, 20, 5034. [CrossRef]

10. Chazelas, P.; Steichen, C.; Favreau, F.; Trouillas, P.; Hannaert, P.; Thuillier, R.; Giraud, S.; Hauet, T.; Guillard, J. Oxidative Stress Evaluation in Ischemia Reperfusion Models: Characteristics, Limits and Perspectives. Int. J. Mol. Sci. 2021, 22, 2366. [CrossRef]

11. Schleicher, J.; Dahmen, U. Computational Modeling of Oxidative Stress in Fatty Livers Elucidates the Underlying Mechanism of the Increased Susceptibility to Ischemia/Reperfusion Injury. Comput. Struct. Biotechnol. J. 2018, 16, 511-522. [CrossRef]

12. Senoner, T.; Schindler, S.; Stättner, S.; Öfner, D.; Troppmair, J.; Primavesi, F. Associations of Oxidative Stress and Postoperative Outcome in Liver Surgery with an Outlook to Future Potential Therapeutic Options. Oxidative Med. Cell. Longev. 2019, $2019,1-18$. [CrossRef]

13. Calabrese, V.; Santoro, A.; Monti, D.; Crupi, R.; di Paola, R.; Latteri, S.; Cuzzocrea, S.; Zappia, M.; Giordano, J.; Calabrese, E.J.; et al. Aging and Parkinson's Disease: Inflammaging, neuroinflammation and biological remodeling as key factors in pathogenesis. Free Radic. Biol. Med. 2018, 115, 80-91. [CrossRef] 
14. Prasad, K.N. Oxidative Stress, Pro-Inflammatory Cytokines, and Antioxidants Regulate Expression Levels of MicroRNAs in Parkinson's Disease. Curr. Aging Sci. 2017, 10, 177-184. [CrossRef]

15. Fung, T.C. The microbiota-immune axis as a central mediator of gut-brain communication. Neurobiol. Dis. 2020, 136, 104714. [CrossRef] [PubMed]

16. Ma, Q.; Xing, C.; Long, W.; Wang, H.Y.; Liu, Q.; Wang, R.-F. Impact of microbiota on central nervous system and neurological diseases: The gutbrain axis. J. Neuroinflam. 2019, 16, 53. [CrossRef]

17. Rodrigues, R.; Petersen, R.B.; Perry, G. Parallels Between Major Depressive Disorder and Alzheimer's Disease: Role of Oxidative Stress and Genetic Vulnerability. Cell Mol. Neurobiol. 2014, 34, 925-949. [CrossRef] [PubMed]

18. Duarte-Silva, E.; Macedo, D.; Maes, M.; Peixoto, C.A. Novel insights into the mechanisms underlying depression-associated experimental autoimmune encephalomyelitis. Prog. Neuro-Psychopharmacol. Biol. Psychiatry 2019, 93, 1-10. [CrossRef] [PubMed]

19. Martin-Subero, M.; Anderson, G.; Kanchanatawan, B.; Berk, M.; Maes, M. Comorbidity between depression and inflammatory bowel disease explained by immune-inflammatory, oxidative, and nitrosative stress; tryptophan catabolite; and gut-brain pathways. CNS Spectr. 2016, 21, 184-198. [CrossRef]

20. Gałecki, P.; Talarowska, M. Inflammatory theory of depression. Psychiatr. Polska. 2018, 52, 437-447. [CrossRef]

21. Black, C.N.; Bot, M.; Scheffer, P.G.; Cuijpers, P.; Penninx, B.W. Is depression associated with increased oxidative stress? A systematic review and meta-analysis. Psychoneuroendocrinology 2015, 51, 164-175. [CrossRef] [PubMed]

22. Lindqvist, D.; Dhabhar, F.S.; James, S.J.; Hough, C.M.; Jain, F.A.; Bersani, F.S.; Reus, V.; Verhoeven, J.E.; Epel, E.S.; Mahan, L.; et al. Oxidative stress, inflammation and treatment response in major depression. Psychoneuroendocrinology 2017, 76, 197-205. [CrossRef] [PubMed]

23. Fedoce, A.; Das, G.; Ferreira, F.; Bota, R.G.; Bonet-Costa, V.; Sun, P.Y.; Davies, K.J.A. The role of oxidative stress in anxiety disorder: Cause or consequence. In Free Radical Research; Taylor and Francis Ltd.: New York, NY, USA, 2018; Volume 52, pp. 737-750. [CrossRef]

24. Markowiak-Kopeć, P.; Śliżewska, K. Effects of Probiotics, Prebiotics, and Synbiotics on Human Health. Nutrients 2017, 9, 1021. [CrossRef]

25. Mishra, V.; Shah, C.; Mokashe, N.; Chavan, R.; Yadav, H.; Prajapati, J. Probiotics as Potential Antioxidants: A Systematic Review. J. Agric. Food Chem. 2015, 63, 3615-3626. [CrossRef] [PubMed]

26. Nowak, A.; Paliwoda, A.; Błasiak, J. Anti-proliferative, pro-apoptotic and anti-oxidative activity of Lactobacillus and Bifidobacterium strains: A review of mechanisms and therapeutic perspectives. Crit. Rev. Food Sci. Nutr. 2019, 59, 3456-3467. [CrossRef] [PubMed]

27. Moradi, M.; Kousheh, S.A.; Almasi, H.; Alizadeh, A.; Guimarães, J.T.; Yılmaz, N.; Lotfi, A. Postbiotics produced by lactic acid bacteria: The next frontier in food safety. Compr. Rev. Food Sci. Food Saf. 2020, 19, 3390-3415. [CrossRef]

28. Amaretti, A.; Di Nunzio, M.; Pompei, A.; Raimondi, S.; Rossi, M.; Bordoni, A. Antioxidant properties of potentially probiotic bacteria: In vitro and in vivo activities. Appl. Microbiol. Biotechnol. 2013, 97, 809-817. [CrossRef]

29. Wang, Y.; Wu, Y.; Wang, Y.; Xu, H.; Mei, X.; Yu, D.; Wang, Y.; Li, W. Antioxidant Properties of Probiotic Bacteria. Nutrients 2017, 9, 521. [CrossRef]

30. Feng, T.; Wang, J. Oxidative stress tolerance and antioxidant capacity of lactic acid bacteria as probiotic: A systematic review. Gut Microbes 2020, 12, e1801944. [CrossRef]

31. Hoffmann, A.; Kleniewska, P.; Pawliczak, R. Antioxidative activity of probiotics. Arch. Med. Sci. 2021, 17, 792-804. [CrossRef]

32. Wong, C.; Sugahara, H.; Odamaki, T.; Xiao, J. Different physiological properties of human-residential and non-human-residential bifidobacteria in human health. Benef. Microbes 2018, 9, 111-122. [CrossRef]

33. Turroni, F.; Milani, C.; Ventura, M.; van Sinderen, D. The human gut microbiota during the initial stages of life: Insights from bifidobacteria. Cur. Opin. Biotechn. 2021, 73, 81-87. [CrossRef]

34. Turroni, F.; Milani, C.; Duranti, S.; Ferrario, C.; Lugli, G.A.; Mancabelli, L.; Van Sinderen, D.; Ventura, M. Bifidobacteria and the infant gut: An example of co-evolution and natural selection. Cell. Mol. Life Sci. 2018, 75, 103-118. [CrossRef] [PubMed]

35. Salvetti, E.; O'Toole, P.W. When regulation challenges innovation: The case of the genus Lactobacillus. Trends Food Scie. Tech. 2017, 66, 187-194. [CrossRef]

36. Arboleya, S.; Watkins, C.; Stanton, C.; Ross, R.P. Gut Bifidobacteria Populations in Human Health and Aging. Front. Microbiol. 2016, 7, e1204. [CrossRef] [PubMed]

37. Stavropoulou, E.; Bezirtzoglou, E. Probiotics in Medicine: A Long Debate. Front. Immunol. 2020, 11, e2192. [CrossRef]

38. Averina, O.V.; Kovtun, A.S.; Polyakova, S.I.; Savilova, A.M.; Rebrikov, D.V.; Danilenko, V.N. The bacterial neurometabolic signature of the gut microbiota of young children with autism spectrum disorders. J. Med. Microbiol. 2020, 69, 558-571. [CrossRef] [PubMed]

39. Averina, O.V.; Zorkina, Y.A.; Yunes, R.A.; Kovtun, A.S.; Ushakova, V.M.; Morozova, A.Y.; Kostyuk, G.P.; Danilenko, V.N.; Chekhonin, V.P. Bacterial Metabolites of Human Gut MicrobiotaCorrelating with Depression. Int. J. Mol. Sci. 2020, $21,9234$. [CrossRef]

40. Wong, C.B.; Odamaki, T.; Xiao, J.Z. Insights into the reason of Human-Residential Bifidobacteria (HRB) being the natural inhabitants of the human gut and their potential health promoting benefits. FEMS Microbiol. Rev. 2020, 44, 369-385. [CrossRef]

41. Rivière, A.; Selak, M.; Lantin, D.; Leroy, F.; De Vuyst, L. Bifidobacteria and Butyrate-Producing Colon Bacteria: Importance and Strategies for Their Stimulation in the Human Gut. Front. Microb. 2016, 7, 979. [CrossRef] 
42. Kawasaki, S.; Watanabe, M.; Fukiya, S.; Yokota, A. Chapter 7-Stress Responses of Bifidobacteria: Oxygen and Bile Acid as the Stressors. The Bifidobacteria and Related Organisms. Biol. Taxon. Appl. 2018, 10, 131-143.

43. Duar, R.M.; Lin, X.B.; Zheng, J.; Martino, M.E.; Grenier, T.; Pérez-Muñoz, M.E.; Leulier, F.; Gänzle, M.; Walter, J. Lifestyles in transition: Evolution and natural history of the genus Lactobacillus. FEMS Microbiol. Rev. 2017, 41, S27-S48. [CrossRef] [PubMed]

44. Zhang, Z.; Lv, J.; Pan, L.; Zhang, Y. Roles and applications of probiotic Lactobacillus strains. Appl. Microbiol. Biotechnol. 2018, 102, 8135-8143. [CrossRef] [PubMed]

45. Rossi, M.; Martínez-Martínez, D.; Amaretti, A.; Ulrici, A.; Raimondi, S.; Moya, A. Mining metagenomic whole genome se-quences revealed subdominant but constant Lactobacillus population in the human gut microbiota. Environ. Microbiol. 2016, 8, 399-406.

46. Kono, Y.; Fridovich, I. Isolation and characterization of the pseudocatalase of Lactobacillus plantarum. J. Biolog. Chem. 1983, 258, 6015-6019. [CrossRef]

47. Million, M.; Raoult, D. Linking gut redox to human microbiome. Hum. Microbiome J. 2018, 10, 27-32. [CrossRef]

48. Wang, H.; Wang, G.; Banerjee, N.; Liang, Y.; Du, X.; Boor, P.J.; Hoffman, K.L.; Khan, M.F. Aberrant Gut Microbiome Contrib-utes to Intestinal Oxidative Stress, Barrier Dysfunction, Inflammation and Systemic Autoimmune Responses in MRL/lpr Mice. Front. Immunol. 2021, 12, 651191. [CrossRef] [PubMed]

49. O'Toole, P.W.; Cooney, J. Probiotic Bacteria Influence the Composition and Function of the Intestinal Microbiota. Interdiscip. Perspect. Infect. Dis. 2008, 2008, 1-9. [CrossRef]

50. Doron, S.; Gorbach, S.L. Probiotics: Their role in the treatment and prevention of disease. Expert Rev. Anti-Infect. Ther. 2006, 4, 261-275. [CrossRef]

51. Novik, G.; Savich, V. Beneficial microbiota. Probiotics and pharmaceutical products in functional nutrition and medicine. Microbes Infect. 2020, 22, 8-18. [CrossRef]

52. Heinemann, C.; Vlieg, J.E.T.V.; Janssen, D.B.; Busscher, H.J.; van der Mei, H.C.; Reid, G. Purification and characterization of a surface-binding protein from Lactobacillus fermentum RC-14 that inhibits adhesion of Enterococcus faecalis 1131. FEMSMicrobiol. Lett. 2000, 190, 177-180. [CrossRef] [PubMed]

53. Li, K.; Duan, C.; Wang, C.; Clain, M.; Feng, W. Probiotics and alcoholic liver disease: Treatment and potential mechanisms Gastroenter. Resea. Pract. 2016, 2016, 1-11. [CrossRef] [PubMed]

54. Sugahara, H.; Odamaki, T.; Fukuda, S.; Kato, T.; Xiao, J.-Z.; Abe, F.; Kikuchi, J.; Ohno, H. Probiotic Bifidobacterium longum alters gut luminal metabolism through modification of the gut microbial community. Sci. Rep. 2015, 5, 13548. [CrossRef]

55. Wang, B.G.; Xu, H.B.; Wei, H.; Zeng, Z.L.; Xu, F. Oral administration of Bifidobacterimbifidum for modulating microflora, acid and bile resistance, and physiological indices in mice. Can. J. Microbiol. 2015, 61, 155-163. [CrossRef]

56. Gagnon, M.; Savard, P.; Riviére, A.; LaPointe, G.; Roy, D. Bioaccessible antioxidants in milk fermented by Bifidobacterium longum subsp. longum strains. Biomed. Res. Int. 2015, 2015, e169381. [CrossRef]

57. Lin, M.Y.; Chang, F.J. Antioxidative effect of intestinal bacteria Bifidobacterium longum ATCC 15708 and Lactobacillus acidophilus ATCC 4356. Dig. Dis. Sci. 2000, 45, 1617-1622. [CrossRef]

58. Shen, Q.; Zhang, B.; Xu, R.; Wang, Y.; Ding, X.; Li, P. Antioxidant activity in vitro of the selenium-contained protein from the Se-enriched Bifidobacterium animalis 01. Anaerobe 2010, 16, 380-386. [CrossRef] [PubMed]

59. Shen, Q.; Shang, N.; Li, P. In vitro and in vivo antioxidant activity of Bifidobacterium animalis 01 isolated from centenari-ans. Curr. Microbiol. 2011, 62, 1097-1103. [CrossRef] [PubMed]

60. Lin, M.Y.; Yen, C.L. Inhibition of lipid peroxidation by Lactobacillus acidophilus and Bifidobacterium longum. J. Agric. Food Chem. 1999, 47, 3661-3664. [CrossRef]

61. Marsova, M.; Abilev, S.; Poluektova, E.; Danilenko, V. A bioluminescent test system reveals valuable antioxidant properties of lactobacillus strains from human microbiota. World J. Microbiol. Biotechnol. 2018, 34, 27. [CrossRef]

62. Xing, J.; Wang, G.; Zhang, Q.; Liu, X.; Yin, B.; Fang, D.; Zhao, J.; Zhang, H.; Chen, Y.Q.; Chen, W. Determining antioxidant activities of lactobacilli by cellular antioxidant assay in mammal cells. J. Funct. Foods 2015, 19, 554-562. [CrossRef]

63. Liu, Z.; Dong, L.; Jia, K.; Zhan, H.; Zhang, Z.; Shah, N.P.; Tao, X. Sulfonation of Lactobacillus plantarum WLPL04 exopolysaccharide amplifies its antioxidant activities in vitro and in a Caco2 cell model. J. Dairy Sci. 2019, 102, 5922-5932. [CrossRef] [PubMed]

64. Achuthan, A.A.; Duary, R.K.; Madathil, A.; Panwar, H.; Kumar, H.; Batish, V.K.; Grover, S. Antioxidative potential of lactobacilli isolated from the gut of Indian people. Mol. Biol. Rep. 2012, 39, 7887-7897. [CrossRef] [PubMed]

65. Wang, Y.; Fang, Z.; Zhai, Q.; Cui, S.; Zhao, J.; Zhang, H.; Chen, W.; Lu, W. Supernatants of Bifidobacterium longum and Lac-tobacillus plantarum Strains Exhibited Antioxidative Effects on A7R5 Cells. Microorganisms 2021, 9, 452. [CrossRef]

66. Choi, S.S.; Kim, Y.; Han, K.S.; You, S.; Oh, S.; Kim, S.H. Effects of Lactobacillus strains on cancer cell proliferation and oxida-tive stress in vitro. Lett. Appl. Microbiol. 2006, 42, 452-458. [CrossRef] [PubMed]

67. Zhao, X.; Yi, R.; Zhou, X.; Mu, J.; Long, X.; Pan, Y.; Song, J.-L.; Park, K.-Y. Preventive effect of Lactobacillus plantarum KSFY02 isolated from naturally fermented yogurt from Xinjiang, China, on d-galactose-induced oxidative aging in mice. J. Dairy Sci. 2019, 102, 5899-5912. [CrossRef] [PubMed]

68. Noureen, S.; Riaz, A.; Arshad, M.; Arshad, N. In vitro selection and in vivo confirmation of the antioxidant ability of Lactobacillus brevis MG 000874. J. Appl. Microbiol. 2019, 126, 1221-1232. [CrossRef]

69. Wanchao, S.; Chen, M.; Zhiguo, S.; Futang, X.; Mengmeng, S. Protective effect and mechanism of Lactobacillus on cerebral ischemia reperfusion injury in rats. Braz. J. Med. Biol. Res. 2018, 51, e7172. [CrossRef] 
70. Tang, J.; Guo, C.; Gong, F. Protective effect of Lactobacillus reuteri against oxidative stress in neonatal mice with necrotiz-ing enterocolitis. Nan Fang Yi Ke Da XueXue Bao 2019, 39, 1221-1226.

71. Marsova, M.; Odorskaya, M.; Novichkova, M.D.; Polyakova, V.; Abilev, S.; Kalinina, E.V.; Shtil, A.; Poluektova, E.; Danilenko, V. The Lactobacillus brevis $47 \mathrm{f}$ Strain Protects the Murine Intestine from Enteropathy Induced by 5-Fluorouracil. Microorganisms 2020, 8, 876. [CrossRef]

72. Marsova, M.V.; Poluektova, E.U.; Odorskaya, M.V.; Ambaryan, A.V.; Revishchin, A.V.; Pavlova, G.S.; Danilenko, V.N. Pro-tective effects of Lactobacillus fermentum U-21 against paraquat-induced oxidative stress in Caenorhabditis elegans and mouse models. World J. Microbiol. Biotech. 2020, 36, 104. [CrossRef] [PubMed]

73. Grompone, G.; Martorell, P.; Llopis, S.; González, N.; Genovés, S.; Mulet, A.P.; Fernández-Calero, T.; Tiscornia, I.; Bollati-Fogolín, M.; Chambaud, I.; et al. Anti-Inflammatory Lactobacillus rhamnosus CNCM I-3690 Strain Protects against Oxidative Stress and Increases Lifespan in Caenorhabditis elegans. PLoS ONE 2012, 7, e52493. [CrossRef] [PubMed]

74. Soleimani, A.; Mojarrad, M.Z.; Bahmani, F.; Taghizadeh, M.; Ramezani, M.; Tajabadi-Ebrahimi, M.; Jafari, P.; Esmaillzadeh, A.; Asemi, Z. Probiotic supplementation in diabetic hemodialysis patients has beneficial metabolic effects. Kidney Int. 2017, 91, 435-442. [CrossRef] [PubMed]

75. Miraghajani, M.; Zaghian, N.; Mirlohi, M.; Feizi, A.; Ghiasvand, R. The impact of probiotic soy milk consumption on oxidative stress among type 2 diabetic kidney disease patients: A randomized controlled clinical trial. J. Ren. Nutr. 2017, 27, 317-324. [CrossRef] [PubMed]

76. Heshmati, J.; Farsi, F.; Shokri, F.; Rezaeinejad, M.; Almasi-Hashiani, A.; Vesali, S.; Sepidarkish, M. A systematic review and meta-analysis of the probiotics and synbiotics effects on oxidative stress. J. Funct. Foods. 2018, 46, 66-84. [CrossRef]

77. Zheng, H.J.; Guo, J.; Wang, Q.; Wang, L.; Wang, Y.; Zhang, F.; Huang, W.-J.; Zhang, W.; Liu, W.J.; Wang, Y.; et al. Probiotics, prebiotics, and synbiotics for the improve-ment of metabolic profiles in patients with chronic kidney disease: A systematic review and meta-analysis of randomized controlled trials. Crit. Rev. Food Sci. Nutr. 2021, 61, 577-598. [CrossRef]

78. Chamari, M.; Djazayery, A.; Jalali, M. The effect of daily consumption of probiotic and conventional yogurt on some oxidative stress factors in plasma of young healthy women. ARYA Atheroscler J. 2008, 4, 175-179.

79. Macarro, M.S.; Ávila-Gandía, V.; Pérez-Piñero, S.; Cánovas, F.; García-Muñoz, A.M.; Abellán-Ruiz, M.S.; Victoria-Montesinos, D.; Luque-Rubia, A.J.; Climent, E.; Genovés, S.; et al. Antioxidant Effect of a Probiotic Product on a Model of Oxidative Stress Induced by High-Intensity and Duration Physical Exercise. Antioxidants 2021, 10, 323. [CrossRef]

80. Spyropoulos, B.G.; Misiakos, E.P.; Fotiadis, C.; Stoidis, C.N. Antioxidant Properties of Probiotics and Their Protective Effects in the Pathogenesis of Radiation-Induced Enteritis and Colitis. Dig. Dis. Sci. 2011, 56, 285-294. [CrossRef]

81. Lee, J.; Hwang, K.-T.; Chung, M.-Y.; Cho, D.-H.; Park, C.-S. Resistance of Lactobacillus casei KCTC 3260 to Reactive Oxygen Species (ROS): Role for a Metal Ion Chelating Effect. J. Food Sci. 2005, 70, m388-m391. [CrossRef]

82. Halsey, T.A.; Vazquez-Torres, A.; Gravdahl, D.J.; Fang, F.C.; Libby, S.J. The Ferritin-Like Dps Protein Is Required for Salmonella enterica Serovar Typhimurium Oxidative Stress Resistance and Virulence. Amer. Soc. Microbiol. Infect. Immun. 2004, 72, 1155-1158. [CrossRef]

83. Kwak, W.; Kim, K.; Lee, C.; Lee, C.; Kang, J.; Cho, K.; Yoon, S.H.; Kang, D.K.; Kim, H.; Heo, J.; et al. Comparative analysis of the complete genome of Lactobacillus plantarum GB-LP2 and potential candidate genes for host immune system en-hancement. J. Microbiol. Biotechnol. 2016, 26, 684-692. [CrossRef]

84. Kot, E.; Haloftis, G.; Bezkorovainy, A. Iron accumulation by bifidobacteria at low pO2 and in air: Action of putative ferrox-idase. J. Agric. Food Chem. 1994, 42, 685-688. [CrossRef]

85. Serata, M.; Kiwaki, M.; Iino, T. Functional analysis of a novel hydrogen peroxide resistance gene in Lactobacillus casei strain Shirota. Microbiology 2016, 162, 1885-1894. [CrossRef] [PubMed]

86. Yang, Y.; Yin, J.; Liu, J.; Xu, Q.; Lan, T.; Ren, F.; Hao, Y. The Copper Homeostasis Transcription Factor CopR Is Involved in H2O2 Stress in Lactobacillus plantarum CAUH2. Front. Microbiol. 2017, 8, 2015. [CrossRef] [PubMed]

87. Düz, M.; Doğan, Y.N.; Doğan, I. Antioxidant activitiy of Lactobacillus plantarum, Lactobacillus sake and Lactobacillus curvatus strains isolated from fermented Turkish Sucuk. Anais Acad. Bras. Ciências 2020, 92, e20200105. [CrossRef] [PubMed]

88. Serata, M.; Yasuda, E.; Sako, T. Effect of superoxide dismutase and manganese on superoxide tolerance in Lactobacillus casei strain Shirota and analysis of multiple manganese transporters. Biosci. Microbiota Food Health 2018, 37, 31-38. [CrossRef]

89. Kong, L.; Xiong, Z.; Song, X.; Xia, Y.; Zhang, H.; Yang, Y.; Ai, L. Enhanced Antioxidant Activity in Streptococcus thermophilus by High-Level Expression of Superoxide Dismutase. Front. Microbiol. 2020, 11, 579804. [CrossRef]

90. Glorieux, C.; Calderon, P.B. Catalase, a remarkable enzyme: Targeting the oldest antioxidant enzyme to find a new cancer treatment approach. Biol. Chem. 2017, 398, 1095-1108. [CrossRef]

91. Zotta, T.; Parente, E.; Ricciardi, A. Aerobic metabolism in the genusLactobacillus: Impact on stress response and potential applications in the food industry. J. Appl. Microbiol. 2017, 122, 857-869. [CrossRef]

92. Ricciardi, A.; Ianniello, R.G.; Parente, E.; Zotta, T. Factors affecting gene expression and activity of heme- and manga-nesedependent catalases in Lactobacillus casei strains. Int. J. Food Microbiol. 2018, 280, 66-77. [CrossRef]

93. Lin, J.; Zou, Y.; Cao, K.; Ma, C.; Chen, Z. The impact of heterologous catalase expression and superoxide dismutase overex-pression on enhancing the oxidative resistance in Lactobacillus casei. J. Ind. Microbiol. Biotechnol. 2016, 43, 703-711. [CrossRef]

94. Lyu, C.; Hu, S.; Huang, J.; Luo, M.; Mei, L.; Yao, S. Contribution of the activated catalase to oxidative stress resistance and $\gamma$-aminobutyric acid production in Lactobacillus brevis. Int. J. Food Microbiol. 2016, 5, 302-310. [CrossRef] [PubMed] 
95. O'Callaghan, A.; van Sinderen, D. Bifidobacteria and their role as members of the human gut microbiota. Front. Microbiol. 2016, 7, 925. [CrossRef] [PubMed]

96. Naraki, S.; Igimi, S.; Sasaki, Y. NADH peroxidase plays a crucial role in consuming $\mathrm{H}_{2} \mathrm{O}_{2}$ in Lactobacillus casei IGM394. Biosci. Microbiota Food Health. 2020, 39, 45-56. [CrossRef] [PubMed]

97. Mazzeo, M.F.; Cacace, G.; Peluso, A.; Zotta, T.; Muscariello, L.; Vastano, V.; Parente, E.; Siciliano, R. Effect of inactivation of ccpA and aerobic growth in Lactobacillus plantarum: A proteomic perspective. J. Proteom. 2012, 75, 4050-4061. [CrossRef]

98. Bron, P.A.; Wels, M.; Bongers, R.S.; van Bokhorst-van de Veen, H.; Wiersma, A.; Overmars, L.; Marco, M.L.; Kleerebezem, M. Transcriptomes reveal genetic signatures underlying physiological variations imposed by different fermentation conditions in Lactobacillus plantarum. PLoS ONE 2012, 7, e38720. [CrossRef] [PubMed]

99. Higuchi, M.; Yamamoto, Y.; Kamio, Y. Molecular biology of oxygen tolerance in lactic acid bacteria: Functions of NADH oxidases and Dpr in oxidative stress. J. Biosci. Bioeng. 2000, 90, 484-493. [CrossRef]

100. Ruiz, L.; Gueimonde, M.; Ruas-Madiedo, P.; Ribbera, A.; de los Reyes-Gavilán, C.G.; Ventura, M.; Margolles, A.; Sánchez, B. Molecular clues to understand the aerotolerance phenotype of Bifidobacterium animalis subsp. lactis. Appl. Environ. Microbiol. 2012, 78, 644-650. [CrossRef] [PubMed]

101. Shimamura, S.; Abe, F.; Ishibashi, N.; Miyakawa, H.; Yaeshima, T.; Araya, T.; Tomita, M. Relationshlp Between Oxygen Sen-sitivity and Oxygen Metabolism of Blfldobacterium Species. J. Dairy Sci. 1992, 75, 3296-3306. [CrossRef]

102. Jastrząb, A.; Skrzydlewska, E. Thioredoxin-dependent system. Application of inhibitors. J. Enzym. Inhib. Med. Chem. 2021, 36, 362-371. [CrossRef] [PubMed]

103. Lu, J.; Holmgren, A. The thioredoxin antioxidant system. Free Radic. Biol. Med. 2014, 66, 75-87. [CrossRef] [PubMed]

104. Oberg, T.S.; Broadbent, J.R. Hydrogen Peroxide Resistance in Bifidobacterium Animalis Subsp. Lactis and Bifidobacterium Longum. In Stress and Environmental Regulation of Gene Expression and Adaptation in Bacteria, II; de Bruijn, F.J., Ed.; Wiley: New York, NY, USA, 2016; Volume 2, pp. 638-656.

105. Xiao, M.; Xu, P.; Zhao, J.; Wang, Z.; Zuo, F.; Zhang, J.; Ren, F.; Li, P.; Chen, S.; Ma, H. Oxidative stress-related responses of Bifidobacterium longum subsp. longum BBMN68 at the proteomic level after exposure to oxygen. Microbiology 2011, 157, 1573-1588. [CrossRef]

106. Zuo, F.; Yu, R.; Khaskheli, G.B.; Ma, H.; Chen, L.; Zeng, Z.; Mao, A.; Chen, S. Homologous overexpression of alkyl hydroperoxide reductase subunit $\mathrm{C}(\mathrm{ahpC})$ protects Bifidobacterium longum strain NCC2705 from oxidative stress. Res. Microbiol. 2014, 165, 581-589. [CrossRef] [PubMed]

107. Schell, M.A.; Karmirantzou, M.; Sneletal, B. The genome sequence of Bifidobacterium longum reflects its adaptation to the human gastrointestinal tract. Proc. Natl. Acad. Sci. USA 2002, 99, 14422-14427. [CrossRef]

108. Klijn, A.; Mercenier, A.; Arigoni, F. Lessons from the genomes of bifidobacteria. FEMS Microbiol. Rev. 2005, 29, 491-509. [CrossRef]

109. Oberg, T.S.; Warda, R.E.; Steele, J.L.; Broadbent, J.R. Transcriptome analysis of Bifidobacterium longum strains that show a differential response to hydrogen peroxide stress. J. Biotechn. 2015, 212, 58-64. [CrossRef]

110. Zhai, Z.; Yang, Y.; Wang, H.; Wang, G.; Ren, F.; Li, Z.; Hao, Y. Global transcriptomic analysis of Lactobacillus plantarum CAUH2 in response to hydrogen peroxide stress. Food Microbiol. 2020, 87, e103389. [CrossRef]

111. Serrano, L.M.; Molenaar, D.; Wels, M.; Teusink, B.A.; Bron, P.; de Vos, W.M.; Smid, E.J. Thioredoxin reductase is a key factor in the oxidative stress response of Lactobacillus plantarum WCFS1. Microb. Cell Factories 2007, 6, 29. [CrossRef]

112. Serata, M.; Iino, T.; Yasuda, E.; Sako, T. Roles of thioredoxin and thioredoxin reductase in the resistance to oxidative stress in Lactobacillus casei. Microbiology 2012, 158, 953-962. [CrossRef]

113. Zhai, Z.; Yang, Y.; Wang, J.; Wang, G.; Ren, F.; Hao, Y. Complete genome sequencing of Lactobacillus plantarum CAUH2 reveals a novel plasmid pCAUH203 associated with oxidative stress tolerance. Biotechnology 2019, 9, 1-6. [CrossRef] [PubMed]

114. Kawasaki, S.; Satoh, T.; Todoroki, M.; Niimura, Y. b-Type Dihydroorotate Dehydrogenase Is Purified as a $\mathrm{H}_{2} \mathrm{O}_{2}-\mathrm{Forming} \mathrm{NADH}$ Oxidase from Bifidobacterium bifidum. Appl. Environ. Microbiol. 2009, 75, 629-636. [CrossRef] [PubMed]

115. Delcardayre, S.B.; Davies, J.E. Staphylococcus aureus coenzyme A disulfide reductase, a new subfamily of pyridine nucleotide-disulfide oxidoreductase. Sequence, expression, and analysis of cdr. J. Biol. Chem. 1998, 273, 5752-5757. [CrossRef] [PubMed]

116. Zhang, J.; Wang, S.; Zeng, Z.; Qin, Y.; Li, P. The complete genome sequence of Bifidobacterium animalis subsp. lactis 01 and its integral components of antioxidant defense system. 3 Biotech 2019, 9, 1-7. [CrossRef]

117. Kerksick, C.; Willoughby, D. The Antioxidant Role of Glutathione and N-Acetyl-Cysteine Supplements and Exercise-Induced Oxidative Stress. J. Int. Soc. Sports Nutr. 2005, 2, 38-44. [CrossRef] [PubMed]

118. Pophaly, S.D.; Singh, R.; Pophaly, S.D.; Kaushik, J.K.; Tomar, S.K. Current status and emerging role of glutathione in food grade lactic acid bacteria. Microb. Cell Factories 2012, 11, 114. [CrossRef]

119. Pophaly, S.D.; Poonam, S.; Pophaly, S.D.; Kapila, S.; Nanda, D.K.; Tomar, S.K.; Singh, R. Glutathione biosynthesis and activity of dependent enzymes in food grade lactic acid bacteria harboring multidomain bifunctional fusion gene (gshF). J. Appl. Microbiol. 2017, 123, 194-203. [CrossRef]

120. Xiong, Z.-Q.; Kong, L.-H.; Wang, G.-Q.; Xia, Y.-J.; Zhang, H.; Yin, B.-X.; Ai, L.-Z. Functional analysis and heterologous expression of bifunctional glutathione synthetase from Lactobacillus. J. Dairy Sci. 2018, 101, 6937-6945. [CrossRef]

121. Pittman, M.S.; Robinson, H.C.; Poole, R.K. A Bacterial Glutathione Transporter (Escherichia coli CydDC) Exports Reductant to the Periplasm. J. Biol. Chem. 2005, 280, 32254-32261. [CrossRef] 
122. Al-Madboly, L.A.; Ali, S.M.; Fakharany, E.M.E.; Ragab, A.E.; Khedr, E.G.; Elokely, K.M. Stress-based production, and characterization of glutathione peroxidase and glutathione S-transferase enzymes from Lactobacillus plantarum. Front. Bioeng. Biotechnol. 2020, 8, 78. [CrossRef]

123. Lin, X.; Xia, Y.; Yang, Y.; Wang, G.; Zhou, W.; Ai, L. Probiotic characteristics of Lactobacillus plantarum AR113 and its molecular mechanism of antioxidant. LWT 2020, 126, 109278. [CrossRef]

124. Kullisaar, T.; Songisepp, E.; Aunapuu, M.; Kilk, K.; Arend, A.; Mikelsaar, M.; Rehema, A.; Zilmer, M. Complete glutathione system in probiotic Lactobacillus fermentum ME-3. Appl. Biochem. Microbiol. 2010, 46, 481-486. [CrossRef]

125. Yu, X.; Li, Y.; Wu, Q.; Shah, N.P.; Wei, H.; Xu, F. Genomic analysis for antioxidant property of Lactobacillus plantarum FLPL05 from chinese longevity people. Probiotics Antimicrob. Proteins 2020, 12, 1451-1458. [CrossRef]

126. Elias, R.J.; Kellerby, S.S.; Decker, E.A. Antioxidant activity of proteins and peptides. Crit. Rev. Food Scien. Nutr. 2008, 48, 430-441. [CrossRef] [PubMed]

127. Sánchez, A.; Vázquez, A. Bioactive peptides: A review. Food Qual. Safety 2017, 1, 29-46. [CrossRef]

128. Virtanen, T.; Pihlanto, A.; Akkanen, S.; Korhonen, H. Development of antioxidant activity in milk whey during fermentation with lactic acid bacteria. J. Appl. Microbiol. 2007, 102, 106-115. [CrossRef] [PubMed]

129. Alhaj, O.A.; Kanekanian, A.D.; Peters, A.C.; Tatham, A.S. Hypocholesterolemic Effect of Bifidobacterium animalis Subspecies. Lactis (Bb12) and Trypsin Casein Hydrolysate. Food Chem. 2010, 123, 430-435. [CrossRef]

130. Chang, O.; Seol, K.-H.; Jeong, S.-G.; Oh, M.-H.; Park, B.-Y.; Perrin, C.; Ham, J.-S. Casein hydrolysis by Bifidobacterium longum KACC91563 and antioxidant activities of peptides derived therefrom. J. Dairy Sci. 2013, 96, 5544-5555. [CrossRef]

131. Wada, M.; Fukiya, S.; Suzuki, A.; Matsumoto, N.; Matsuo, M.; Yokota, A. Methionine utilization by bifidobacteria: Possible existence of a reverse transsulfuration pathway. Biosci. Microbiota Food Health 2021, 40, 80-83. [CrossRef] [PubMed]

132. Wlodarska, M.; Luo, C.; Kolde, R.; d'Hennezel, E.; Annand, J.W. Indoleacrylic acid produced by commensal Pepto-streptococcus species suppresses inflammation. Cell Host Microbe 2017, 22, 25-37. [CrossRef]

133. Zelante, T.; Iannitti, R.G.; Cunha, C.; De Luca, A.; Giovannini, G.; Pieraccini, G.; Zecchi, R.; D'Angelo, C.; Massi-Benedetti, C.; Fallarino, F.; et al. Tryptophan catabolites from microbiota engage aryl hydrocarbon receptor and balance mucosal reactivity via interleukin-22. Immunity 2013, 39, 372-385. [CrossRef]

134. Zhao, H.; Jiang, Z.; Chang, X.; Xue, H.; Yahefu, W.; Zhang, X. 4-Hydroxyphenylacetic Acid Prevents Acute APAP-Induced Liver Injury by Increasing Phase II and Antioxidant Enzymes in Mice. Front. Pharmacol. 2018, 9, 653. [CrossRef]

135. Greifová, G.; Body, P.; Greif, G.; Greifová, M.; Dubničková, M. Human phagocytic cell response to histamine derived from potential probiotic strains of Lactobacillus reuteri. Immunobiology 2018, 223, 618-626. [CrossRef] [PubMed]

136. Azuma, Y.-T.; Shinohara, M.; Wang, P.-L.; Hidaka, A.; Ohura, K. Histamine inhibits chemotaxis, phagocytosis, superoxide anion production, and the production of TNF $\alpha$ and IL-12 by macrophages via H2-receptors. Int. Immunopharmacol. 2001, 1, 1867-1875. [CrossRef]

137. Trabelsi, I.; Ktari, N.; Ben Slima, S.; Triki, M.; Bardaa, S.; Mnif, H.; Ben Salah, R. Evaluation of dermal wound healing activity and in vitro antibacterial and antioxidant activities of a new exopolysaccharide produced by Lactobacillus sp.Ca 6. Int. J. Biol. Macromol. 2017, 103, 194-201. [CrossRef] [PubMed]

138. Wang, Y.-C.; Yu, R.-C.; Chou, C.-C. Antioxidative activities of soymilk fermented with lactic acid bacteria and bifidobacteria. Food Microbiol. 2006, 23, 128-135. [CrossRef]

139. Peirotén, Á.; Álvarez, I.; Landete, J.M. Production of flavonoid and lignan aglycones from flaxseed and soy extracts by Bifidobacterium strains. Int. J. Food Sci. Technol. 2019, 55, 2122-2131. [CrossRef]

140. Braune, A.; Blaut, M. Bacterial species involved in the conversion of dietary flavonoids in the human gut. Gut Microbes 2016, 7, 216-234. [CrossRef] [PubMed]

141. Kelly, S.M.; O'Callaghan, J.; Kinsella, M.; Van Sinderen, D. Characterisation of a Hydroxycinnamic Acid Esterase from the Bifidobacterium longum subsp. longum Taxon. Front. Microbiol. 2018, 9, 2690. [CrossRef] [PubMed]

142. Park, C.-M.; Kim, G.-M.; Cha, G.-S. Biotransformation of Flavonoids by Newly Isolated and Characterized Lactobacillus pentosus NGI01 Strain from Kimchi. Microorganisms 2021, 9, 1075. [CrossRef]

143. Rice-Evans, C.A.; Miller, N.J.; Paganga, G. Structure-antioxidant activity relationships of flavonoids and phenolic acids. Free. Radic. Biol. Med. 1996, 20, 933-956. [CrossRef]

144. Bhathena, J.; Kulamarva, A.; Urbanska, A.M.; Martoni, C.; Prakash, S. Microencapsulated bacterial cells can be used to produce the enzyme feruloyl esterase: Preparation and in-vitro analysis. Appl. Microbiol. Biotechnol. 2007, 75, 1023-1029. [CrossRef]

145. Tomaro-Duchesneau, C.; Malhotra, M.; Coussa-Charley, M.; Al-Salami, H.; Jones, M.; Labbe, A. Lactobacillus fermentum NCIMB 5221 has a greater ferulic acid production compared to other ferulic acid esterase producing Lactobacilli. Int. J. Probiotics Prebiotics 2012, 7, 23-32.

146. Mukdsi, M.C.; Cano, M.P.; González, S.N.; Medina, R.B. Administration of Lactobacillus fermentum CRL1446 increases in-testinal feruloyl esterase activity in mice. Lett. Appl. Microbiol. 2012, 54, 18-25. [CrossRef] [PubMed]

147. Mayo, B.; van Sinderen, D. Bifidobacteria: Genomics and Molecular Aspects; Mayo, B., van Sinderen, D., Eds.; Caister Academic Press: Norfolk, UK, 2010.

148. Saha, P.; Yeoh, B.S.; Singh, R.; Chandrasekar, B.; Vemula, P.K.; Haribabu, B.; Vijay-Kumar, M.; Jala, V.R. Gut Microbiota Conversion of Dietary Ellagic Acid into Bioactive Phytoceutical Urolithin a Inhibits Heme Peroxidases. PLoS ONE 2016, 11, e0156811. [CrossRef] [PubMed] 
149. Gaya, P.; Peirotén, Á.; Medina, M.; Álvarez, I.; Landete, J.M. Bifidobacterium pseudocatenulatum INIA P815: The first bacterium able to produce urolithins A and B from ellagic acid. J. Funct. Foods 2018, 45, 95-99. [CrossRef]

150. Kim, M.; Seo, D.H.; Park, Y.S.; Cha, I.T.; Seo, M.J. Isolation of Lactobacillus plantarum subsp. plantarum producing C30 ca-rotenoid 4, $4^{\prime}$-diaponeurosporene and the assessment of its antioxidant activity. J. Microbiol. Biotechnol. 2019, 29, 1925-1930. [CrossRef] [PubMed]

151. McEneny, J.; Couston, C.; McKibben, B.; Young, I.S.; Woodside, J.V. Folate: In vitro and in vivo effects on VLDL and LDL oxidation. Int. J. Vitam. Nutr. Res. 2007, 77, 66. [CrossRef]

152. Yoshii, K.; Hosomi, K.; Sawane, K.; Kunisawa, J. Metabolism of Dietary and Microbial Vitamin B Family in the Regulation of Host Immunity. Front. Nutr. 2019, 6, 48. [CrossRef]

153. Rossi, M.; Amaretti, A.; Raimondi, S. Folate Production by Probiotic Bacteria. Nutrients 2011, 3, 118-134. [CrossRef]

154. Van de Lagemaat, E.E.; de Groot, L.C.P.G.M.; van den Heuvel, E.G.H.M. Vitamin B12 in relation to oxidative stress: A Systematic review. Nutrients 2019, 11, 482. [CrossRef]

155. Danchin, A.; Braham, S. Coenzyme B12 synthesis as a baseline to study metabolite contribution of animal microbiota. Microb. Biotechnol. 2017, 10, 688-701. [CrossRef]

156. Capozzi, V.; Russo, P.; Dueñas, M.T.; López, P.; Spano, G. Lactic acid bacteria producing B-group vitamins: A great potential for functional cereals products. Appl. Microbiol. Biotechnol. 2012, 96, 1383-1394. [CrossRef] [PubMed]

157. Santos, F.; Vera, J.L.; Lamosa, P.; De Valdez, G.F.; De Vos, W.M.; Santos, H.; Sesma, F.; Hugenholtz, J. Pseudovitamin B12 is the corrinoid produced byLactobacillus reuteriCRL1098 under anaerobic conditions. FEBS Lett. 2007, 581, 4865-4870. [CrossRef] [PubMed]

158. Thakur, K.; Tomar, S.K.; De, S. Lactic acid bacteria as a cell factory for riboflavin production. Microb. Biotechnol. $2015,9,441-451$. [CrossRef] [PubMed]

159. Morishita, T.; Tamura, N.; Makino, T.; Kudo, S. Production of manaquinones by lactic acid bacteria. J. Dairy Sci. 1999, 82, 1897-1903. [CrossRef]

160. Lim, S.-D.; Kim, K.-S.; Do, J.-R. Physiological Characteristics and Production of Vitamin K2by Lactobacillus fermentum LC272 Isolated from Raw Milk. Food Sci. Anim. Resour. 2011, 31, 513-520. [CrossRef]

161. Kodali, V.P.; Sen, R. Antioxidant and free radical scavenging activities of an exopolysaccharide from a probiotic bacterium. Biotechnol. J. 2008, 3, 245-251. [CrossRef]

162. Kšonžeková, P.; Bystrický, P.; Vlčková, S.; Pätoprstý, V.; Pulzova, L.B.; Mudroňová, D.; Kubašková, T.M.; Csank, T.; Tkáčiková, L'. Exopolysaccharides of Lactobacillus reuteri: Their influence on adherence of E. coli to epithelial cells and inflammatory response. Carbohydr. Polym. 2016, 141, 10-19. [CrossRef]

163. Saadat, R.Y.; Khosroushahi, Y.A.; Gargari, P.B. A comprehensive review of anticancer, immunomodulatory and health ben-eficial effects of the lactic acid bacteria exopolysaccharides. Carbohydr. Polym. 2019, 217, 79-89. [CrossRef]

164. Polak-Berecka, M.; Waśko, A.; Szwajgier, D.; Choma, A. Bifidogenic and Antioxidant Activity of Exopolysaccharides Produced by Lactobacillus rhamnosus E/N Cultivated on Different Carbon Sources. Pol. J. Microbiol. 2013, 62, 181-188. [CrossRef] [PubMed]

165. Li, B.; Du, P.; Smith, E.E.; Wang, S.; Jiao, Y.; Guo, L.; Huo, G.; Liu, F. In vitro and in vivo evaluation of an exopolysaccharide produced by Lactobacillus helveticus KLDS1.8701 for the alleviative effect on oxidative stress. Food Funct. 2019, 10, 1707-1717. [CrossRef] [PubMed]

166. Deo, D.; Davray, D.; Kulkarni, R. A diverse repertoire of exopolysaccharide biosynthesis gene clusters in Lactobacillus revealed by comparative analysis in 106 sequenced genomes. Microoorganisms 2019, 7, 444. [CrossRef] [PubMed]

167. Nguyen, P.-T.; Nguyen, T.-T.; Bui, D.-C.; Hong, P.-T.; Hoang, Q.-K.; Nguyen, H.-T. Exopolysaccharide production by lactic acid bacteria: The manipulation of environmental stresses for industrial applications. AIMS Microbiol. 2020, 6, 451-469. [CrossRef] [PubMed]

168. Bruno-Bárcena, J.M.; Andrus, J.M.; Libby, S.L.; Klaenhammer, T.R.; Hassan, H.M. Expression of a Heterologous Manganese Superoxide Dismutase Gene in Intestinal Lactobacilli Provides Protection against Hydrogen Peroxide Toxicity. Appl. Environ. Microbiol. 2004, 70, 4702-4710. [CrossRef]

169. Tang, W.; Xing, Z.; Li, C.; Wang, J.; Wang, Y. Molecular mechanisms and in vitro antioxidant effects of Lactobacillus plantarum MA2. Food Chem. 2017, 221, 1642-1649. [CrossRef]

170. Archibald, F.S.; Fridovich, I. Manganese and Defenses against Oxygen Toxicity in Lactobacillus plantarum. J. Bacteriol. 1981, 145, 442-451. [CrossRef]

171. Groot, M.N.N.; Klaassens, E.; de Vos, W.M.; Delcour, J.; Hols, P.; Kleerebezem, M. Genome-based in silico detection of putative manganese transport systems in Lactobacillus plantarum and their genetic analysis. Microbiology 2005, 151, 1229-1238. [CrossRef]

172. Pana, Y.; Wang, H.; Tan, F.; Yi, R.; Li, W.; Long, X.; Mu, J.; Zhao, X. Lactobacillus plantarum KFY02 enhances the prevention of $\mathrm{CCl}$-induced liver injury by transforming geniposide into genipin to increase the antioxidant capacity of mice. J. Funct. Foods 2020, 73, e104128. [CrossRef]

173. Wang, L.-X.; Liu, K.; Gao, D.-W.; Hao, J.-K. Protective effects of two Lactobacillus plantarum strains in hyperlipidemic mice. World, J. Gastroenterol. 2013, 19, 3150-3156. [CrossRef]

174. Saeedi, B.; Liu, K.H.; Owens, J.A.; Hunter-Chang, S.; Camacho, M.C.; Eboka, R.U.; Chandrasekharan, B.; Baker, N.F.; Darby, T.; Robinson, B.S.; et al. Gut-Resident Lactobacilli Activate Hepatic Nrf2 and Protect Against Oxidative Liver Injury. Cell Metab. 2020, 31, 956-968.e5. [CrossRef] 
175. Singh, C.K.; Chhabra, G.; Ndiaye, M.A.; Garcia-Peterson, L.M.; Mack, N.J.; Ahmad, N. The Role of Sirtuins in Antioxidant and Redox Signaling. Antioxid. Redox Signal. 2018, 28, 643-661. [CrossRef]

176. Guo, Q.; Li, S.; Xie, Y.; Zhang, Q.; Liu, M.; Xu, Z.; Sun, H.; Yang, Y. The NAD+-dependent deacetylase, Bifidobacterium longum Sir2 in response to oxidative stress by deacetylating SigH $(\sigma \mathrm{H})$ and FOXO3a in Bifidobacterium longum and HEK293T cell respectively. Free Radic. Biol. Med. 2017, 108, 929-939. [CrossRef]

177. Huang, G.; Pan, H.; Zhu, Z.; Li, Q. The complete genome sequence of Bifidobacterium longum LTBL16, a potential probiotic strain from healthy centenarians with strong antioxidant activity. Genome 2020, 112, 769-773. [CrossRef]

178. Chang, L.; Karin, M. Mammalian MAP kinase signalling cascades. Nat. Cell Biol. 2001, 410, 37-40. [CrossRef]

179. Tao, Y.; Drabik, K.A.; Waypa, T.S.; Musch, M.W.; Alverdy, J.C.; Schneewind, O.; Chang, E.B.; Petrof, E.O. Soluble factors from Lactobacillus GG activate MAPKs and induce cytoprotective heat shock proteins in intestinal epithelial cells. Am. J. Physiol. Cell Physiol. 2006, 290, 1018-1030. [CrossRef] [PubMed]

180. Nakagawa, H.; Shiozaki, T.; Kobatake, E.; Hosoya, T.; Moriya, T.; Sakai, F.; Taru, H.; Miyazaki, T. Effects and mechanisms of prolongevity induced by Lactobacillus gasseri SBT2055 in Caenorhabditis elegans. Aging Cell 2015, 15, 227-236. [CrossRef]

181. Kobatake, E.; Nakagawa, H.; Seki, T.; Miyazaki, T. Protective effects and functional mechanisms of Lactobacillus gasseri SBT2055 against oxidative stress. PLoS ONE 2017, 12, e0177106. [CrossRef]

182. Gopalakrishna, R.; Jaken, S. Protein kinase C signaling and oxidative stress. Free Radic. Biol. Med. 2000, 28, 1349-1361. [CrossRef]

183. Zhou, Y.-K.; Qin, H.-L.; Zhang, M.; Shen, T.-Y.; Chen, H.-Q.; Ma, Y.-L. Effects of Lactobacillus plantarum on gut barrier function in experimental obstructive jaundice. World J. Gastroenterol. 2012, 14, 3977-3991. [CrossRef] [PubMed]

184. Seth, A.; Yan, F.; Polk, D.B.; Rao, R.K. Probiotics ameliorate the hydrogen peroxide-induced epithelial barrier disruption by a PKC- and MAP kinase-dependent mechanism. Am. J. Physiol. Liver Physiol. 2008, 294, G1060-G1069. [CrossRef] [PubMed]

185. Petrof, E.O.; Kojima, K.; Ropeleski, M.J.; Musch, M.W.; Tao, Y.; De Simone, C.; Chang, E.B. Probiotics inhibit nu-clear factorкарраB and induce heat shock proteins in colonic epithelial cells through proteasome inhibition. Gastroenterology 2004, 127, 1474-1487. [CrossRef] [PubMed]

186. Vancamelbeke, M.; Vermeire, S. The intestinal barrier: A fundamental role in health and disease. Expert Rev. Gastroenterol. Hepatol. 2017, 11, 821-834. [CrossRef] [PubMed]

187. Sommer, F.; Anderson, J.M.; Bharti, R.; Raes, J.; Rosenstiel, P. The resilience of the intestinal microbiota infuences health and disease. Nat. Rev. Microbiol. 2017, 15, 630-638. [CrossRef] [PubMed]

188. Ghosh, S.; Whitley, C.S.; Haribabu, B.; Jala, V.R. Regulation of Intestinal Barrier Function by Microbial Metabolites. Cell. Mol. Gastroenterol. Hepatol. 2021, 11, 1463-1482. [CrossRef]

189. Roche, H.M.; Terres, A.M.; Black, I.B.; Gibney, M.J.; Kelleher, D. Fatty acids and epithelial permeability: Effect of conjugated linoleic acid in Caco-2 cells. Gut 2001, 48, 797-802. [CrossRef]

190. Macdonald, H.B. Conjugated Linoleic Acid and Disease Prevention: A Review of Current Knowledge. J. Am. Coll. Nutr. 2000, 19, 111S-118S. [CrossRef]

191. Raimondi, S.; Amaretti, A.; Leonardi, A.; Quartieri, A.; Gozzoli, C.; Rossi, M. Conjugated Linoleic Acid Production by Bifidobacteria: Screening, Kinetic, and Composition. BioMed Res. Int. 2016, 2016, 1-8. [CrossRef]

192. Liu, Q.; Yu, Z.; Tian, F.; Zhao, J.; Zhang, H.; Zhai, Q.; Chen, W. Surface components and metabolites of probiotics for regulation of intestinal epithelial barrier. Microb. Cell Factories 2020, 19, 1-11. [CrossRef]

193. Gao, J.; Li, Y.; Wan, Y.; Hu, T.; Liu, L.; Yang, S.; Gong, Z.; Zeng, Q. A novel postbiotic from Lactobacillus rhamnosus GG with a benefcialefect on intestinal barrier function. Front. Microbiol. 2019, 10, 477. [CrossRef]

194. Ewaschuk, J.B.; Diaz, H.; Meddings, L.; Diederichs, B.; Dmytrash, A.; Backer, J.; Looijer-van Langen, M.; Madsen, K.L. Secreted bioactive factors from Bifdobacteriuminfantis enhance epithelial cell barrier function. Am. J. Physiol. Gastrointest. Liver Physiol. 2008, 295, 1025-1034. [CrossRef]

195. Liu, H.; Wang, J.; He, T.; Becker, S.; Zhang, G.; Li, D.; Ma, X. Butyrate: A Double-Edged Sword for Health? Adv. Nutr. 2018, 9 , 21-29. [CrossRef]

196. Burger-van Paassen, N.; Vincent, A.; Puiman, P.J.; Van Der Sluis, M.; Bouma, J.; Boehm, G.; van Goudoever, J.B.; Van Seuningen, I.; Renes, I.B. The regulation of intestinal mucin MUC2 expression by short-chain fatty acids: Implications for epithelial protection. Biochem. J. 2009, 420, 211-219. [CrossRef]

197. Yin, M.; Yan, X.; Weng, W.; Yang, Y.; Gao, R.; Liu, M.; Pan, C.; Zhu, Q.; Li, H.; Wei, Q.; et al. Micro integral membrane protein (MIMP), a newly dis-covered anti-infammatory protein of Lactobacillus Plantarum, enhances the gut barrier and modulates microbiota and infammatory cytokines. Cell Physiol. Biochem. 2018, 45, 474-490. [CrossRef]

198. O'Connell Motherway, M.; Houston, A.; O'Callaghan, G.; Reunanen, J.; O’Brien, F.; O’Driscoll, T.; Casey, P.G.; de Vos, W.M.; van Sinderen, D.; Shanahan, F. A Bifdobacterial pilus-associated protein promotes colonic epithelial proliferation. Mol. Microbiol. 2019, 111, 287-301. [CrossRef]

199. Jia, F.-F.; Zhang, L.-J.; Pang, X.-H.; Gu, X.-X.; Abdelazez, A.; Liang, Y.; Sun, S.-R.; Meng, X.-C. Complete genome sequence of bacteriocin-producing Lactobacillus plantarum KLDS1.0391, a probiotic strain with gastrointestinal tract resistance and adhesion to the intestinal epithelial cells. Genome 2017, 109, 432-437. [CrossRef]

200. Dubbs, J.M.; Mongkolsuk, S. Peroxiredoxins in Bacterial Antioxidant Defense. Subcell. Biochem. 2007, 44, 143-193. [CrossRef] [PubMed] 
201. Wilkins, L.J.; Monga, M.; Aaron, W.M. Defning Dysbiosis for a Cluster of Chronic Diseases. Sci. Rep. 2019, 9, 12918. [CrossRef] [PubMed]

202. Rani, A.; Saini, K.C.; Bast, F.; Mehariya, S.; Bhatia, S.K.; Lavecchia, R.; Zuorro, A. Microorganisms: A Potential Source of Bioactive Molecules for Antioxidant Applications. Molecules 2021, 26, 1142. [CrossRef]

203. Dixit, Y.; Wagle, A.; Vakil, B. Patents in the Field of Probiotics, Prebiotics, Synbiotics: A Review. J. Food Microbiol. Saf. Hyg. 2016, 1, 111. [CrossRef]

204. Kovtun, A.S.; Averina, O.V.; Zakharevich, N.V.; Kasianov, A.S.; Danilenko, V.N. In silico Identification of Metagenomic Signature Describing Neurometabolic Potential of Normal Human Gut Microbiota. Russ. J. Genet. 2018, 54, 1101-1110. [CrossRef]

205. Benakis, C.; Martin-Gallausiaux, C.; Trezzi, J.-P.; Melton, P.; Liesz, A.; Wilmes, P. The microbiome-gut-brain axis in acute and chronic brain diseases. Curr. Opin. Neurobiol. 2020, 61, 1-9. [CrossRef]

206. Belkina, T.V.; Averina, O.V.; Savenkova, E.V.; Danilenko, V.N. Human Intestinal Microbiome and the Immune System: The Role of Probiotics in Shaping an Immune System Unsusceptible to COVID-19 Infection. Biol. Bull. Rev. 2021, 11, 329-343. [CrossRef]

207. Danilenko, V.N.; Marsova, M.V.; Poluektova, E.U.; Odorskaya, M.V.; Yunes, R.A. Lactobacillus Fermentum U-21 Strain, Which Produces Complex of Biologically Active Substances Which Neutralize Superoxide Anion Induced by Chemical Agents. Patent RU0002705250, 2019.

208. Danilenko, V.N.; Marsova, M.V.; Poluektova, E.U. The Use of Cells of the Lactobacillus Fermentum u-21 Strain and Biologically Active Substances Obtained from Them. Patent RU2019141103, 2021.

209. Danilenko, V.N.; Stavrovskaya, A.V.; Voronkov, D.; Gushchina, A.S.; Marsova, M.; Yamshchikova, N.G.; Ol'shansky, A.S.; Ivanov, M.V.; Illarioshkin, S.N. The use of a pharmabiotic based on the Lactobacillus fermentum U-21 strain to modulate the neurodegenerative process in an experimental model of parkinson's disease. Ann. Clin. Experim. Neurol. 2020, 14, 62-69.

210. Khatoon, F.; Prasad, K.; Kumar, V. COVID-19 associated nervous system manifestations. Sleep Med. 2021, 1-6. [CrossRef]

211. Yeoh, Y.K.; Zuo, T.; Lui, G.C.-Y.; Zhang, F.; Liu, Q.; Li, A.Y.; Chung, A.C.; Cheung, C.P.; Tso, E.Y.; Fung, K.S.; et al. Gut microbiota composition reflects disease severity and dysfunctional immune responses in patients with COVID-19. Gut 2021, 70, 698-706. [CrossRef] [PubMed]

212. Din, A.U.; Mazhar, M.; Waseem, M.; Ahmad, W.; Bibi, A.; Hassan, A.; Ali, N.; Gang, W.; Qian, G.; Ullah, R.; et al. Sars-cov-2 microbiome dysbiosis linked disorders and possible probiotics role. Biomed. Pharmacother. 2021, 133, e110947. [CrossRef] [PubMed]

213. Dyakov, I.N.; Mavletova, D.A.; Chernyshova, I.N.; Snegireva, N.A.; Gavrilova, M.V.; Bushkova, K.K.; Dyachkova, M.S.; Alekseeva, M.G.; Danilenko, V.N. FN3 protein fragment containing two type III fibronectin domains from B. longum GT15 binds to human tumor necrosis factor alpha in vitro. Anaerobe 2020, 65, e102247. [CrossRef] [PubMed]

214. Nezametdinova, V.Z.; Yunes, R.A.; Dukhinova, M.S.; Alekseeva, M.G.; Danilenko, V.N. The Role of the PFNA Operon of Bifidobacteria in the Recognition of Host's Immune Signals: Prospects for the Use of the FN3 Protein in the Treatment of COVID-19. Int. J. Mol. Sci. 2021, 22, 9219. [CrossRef]

215. Todorov, S.D.; Tagg, J.R.; Ivanova, I.V. Could Probiotics and Postbiotics Function as "Silver Bullet" in the Post-COVID-19 Era? Probiot Antimicrob. Proteins 2021, 13, 1-9.

216. Salminen, S.; Collado, M.C.; Endo, A.; Hill, C.; Lebeer, S.; Quigley, E.M.M.; Sanders, M.E.; Shamir, R.; Swann, J.R.; Szajewska, H.; et al. The International Scientific Association of Probiotics and Prebiotics (ISAPP) consensus statement on the defi-nition and scope of postbiotics. Nat. Rev. Gastroenterol. Hepatol. 2021, 18, 649-667. [CrossRef]

217. Poluektova, E.; Yunes, R.; Danilenko, V. The Putative Antidepressant Mechanisms of Probiotic Bacteria: Relevant Genes and Proteins. Nutrients 2021, 13, 1591. [CrossRef]

218. Xu, C.; Qiao, L.; Guo, Y.; Ma, L.; Cheng, Y. Preparation, characteristics and antioxidant activity of polysaccharides and pro-teinscapped selenium nanoparticles synthesized by Lactobacillus casei ATCC 393. Carbohydr. Polym. 2018, 195, 576-585. [CrossRef] [PubMed]

219. Molina-Tijeras, J.A.; Gálvez, J.; Rodríguez-Cabezas, M.E. The Immunomodulatory Properties of Extracellular Vesicles Derived from Probiotics: A Novel Approach for the Management of Gastrointestinal Diseases. Nutrients 2019, 11, 1038. [CrossRef] [PubMed]

220. Keita, N. Extracellular vesicles produced by Bifidobacterium longum export mucin-binding proteins. Appl. Environm. Microbiol. 2020, 86, e01464-20.

221. Valles-Colomer, M.; Falony, G.; Darzi, Y.; Tigchelaar, E.F.; Wang, J.; Tito, R.Y.; Schiweck, C.; Kurilshikov, A.; Joossens, M.; Wijmenga, C.; et al. The neuroactive potential of the human gut microbiota in quality of life and depression. Nat. Microbiol. 2019, 4, 623-632. [CrossRef] [PubMed] 